\title{
Glacier change in the Cariboo Mountains, British Columbia, Canada (1952-2005)
}

\author{
M. J. Beedle, B. Menounos, and R. Wheate \\ Geography Program, University of Northern British Columbia, Prince George, BC, Canada \\ Correspondence to: M. J. Beedle (beedlem@unbc.ca)
}

Received: 20 May 2014 - Published in The Cryosphere Discuss.: 25 June 2014

Revised: 3 November 2014 - Accepted: 10 November 2014 - Published: 7 January 2015

\begin{abstract}
We applied photogrammetric methods with aerial photography from 11 different years between 1946 and 2005 to assess changes in area and volume of 33 glaciers in the Cariboo Mountains of British Columbia for the latter half of the 20th century. These are used to identify changes in extent and elevation primarily for the periods 1952-1985, 19852005, and 1952-2005. All glaciers receded during the period 1952-2005; area retreat averaged $-0.19 \pm 0.05 \% \mathrm{a}^{-1}$. From 1952 to 1985, nine glaciers advanced; following 1985 , retreat rates accelerated to $-0.41 \pm 0.12 \% \mathrm{a}^{-1}$. Thinning rates of a subset of seven glaciers likewise accelerated, from $-0.14 \pm 0.04 \mathrm{~m}^{2}$.e. $\mathrm{a}^{-1}(1952-1985)$ to $-0.50 \pm 0.07 \mathrm{~m}$ w.e. $\mathrm{a}^{-1}$ for the period $1985-2005$. Temperatures increased from the earlier to the latter period for the ablation $\left(+0.38^{\circ} \mathrm{C}\right)$ and accumulation $\left(+0.87^{\circ} \mathrm{C}\right)$ seasons, and average precipitation decreased, particularly in the accumulation season $(-32 \mathrm{~mm},-3.2 \%)$. Our comparison of surface area change with glacier morphometry corroborates previous studies that show primary relations between extent change and surface area. We also find that the strength and sign of these relations varied for different epochs. Our results also indicate that the 1985 glacier extent for the study area reported previously by other studies may be slightly overestimated due to errant mapping of late-lying snow cover.
\end{abstract}

\section{Introduction}

Glaciers are important components of the hydrologic system. They contribute meltwater along with organic and inorganic materials to freshwater systems (Bogdal et al., 2009; Hood et al., 2009; Moore et al., 2009; Marshall et al., 2011). These inputs, along with downstream impacts, are altered when glaciers undergo changes in extent and volume. As glaciers and ice caps (GIC; all glaciers outside of the Antarctic and Greenland ice sheets) lose volume, sea level rises (Radić and Hock, 2011). The largest GIC contributions to sea level rise include the Canadian Arctic Archipelago and Gulf of Alaska regions (Gardner et al., 2011; Berthier et al., 2010), but recent work demonstrates that, collectively, small glaciers $\left(<1 \mathrm{~km}^{2}\right)$ contribute a significant amount to total GIC volume (Bahr and Radić, 2012).

Recent studies of glacier change use a variety of remotely sensed products that include aerial photography (Koblet et al., 2010; Tennant et al., 2012), satellite imagery (Paul et al., 2004; Berthier et al., 2010), and laser altimetry (Sapiano et al., 1998; Arendt et al., 2002). Typically these studies employ a combination of geomatic data to assess changes in glaciers for a particular region (Schiefer et al., 2007; Abermann et al., 2009; Bolch et al., 2010). Comprehensive inventories of glacier extent and change (e.g., Bolch et al., 2010), as well as measurement of glacier volume change of large regions (e.g., Schiefer et al., 2007) primarily rely on satellite-borne instruments. Such analysis is therefore limited to the last 30 years.

Aerial photography can be used to extend glacier change documentation by up to three decades prior to the beginning of the satellite era. In British Columbia, repeat aerial surveys have been approximately decadal, and thus an opportunity exists to assess multi-decadal changes in the area and volume of alpine glaciers. DeBeer and Sharp (2007), for example, combined aerial photography and satellite imagery to assess changes in glacier cover in the southern Canadian Cordillera over the second half of the 20th century. In particular, they noted negligible change in small glaciers in their study. Our study builds on DeBeer and Sharp (2007) by expanding the spatial domain over which glacier change is evaluated and by 


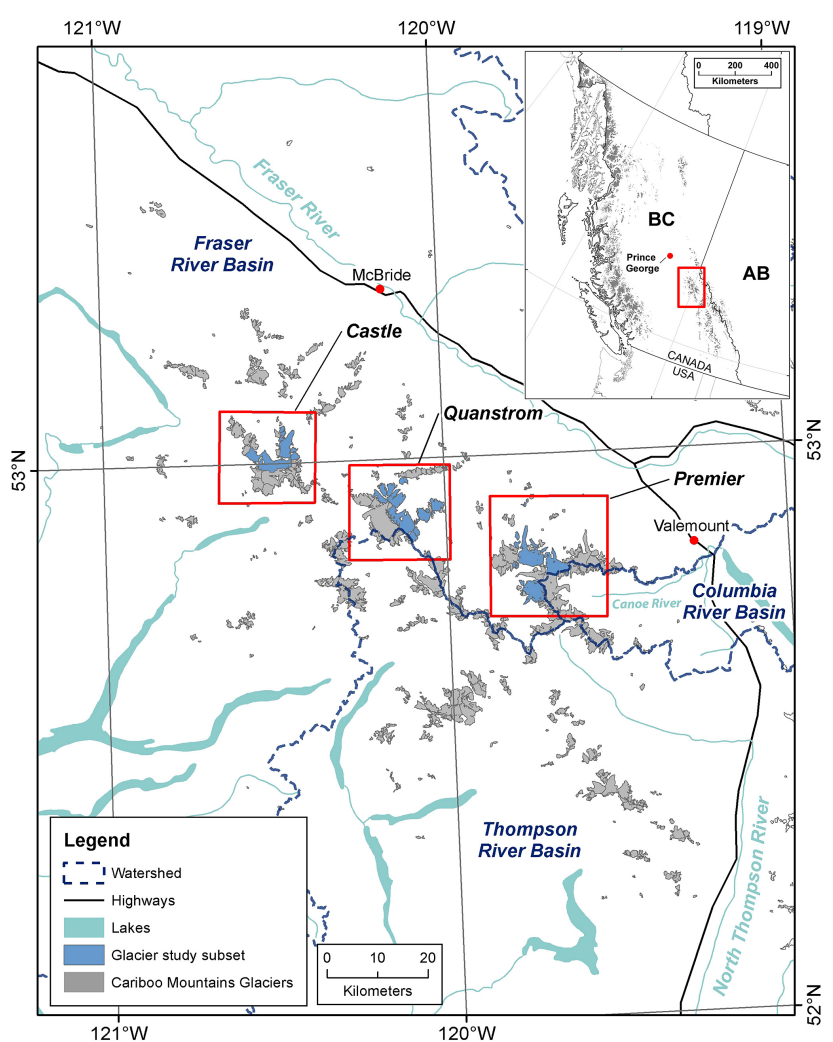

Figure 1. Study area: the three red rectangles indicate subregions in this study (Castle, Quanstrom, and Premier) and the location of the three maps in Fig. 2.

increasing the number of epochs over which these changes can be compared to the instrumental record.

In this study we use aerial photogrammetry to investigate the extent and volume change of a subset of glaciers in western Canada for the periods 1952-1970, 1970-1985, and 1985-2005. The use of aerial photography thus provides a method to temporally extend the glacier inventory studies of Schiefer et al. (2007) and Bolch et al. (2010) and, in addition, an independent check against glacier mapping using lower-resolution satellite imagery.

The objectives of this study are to (1) document the extent and volume change of a subset of glaciers in the Cariboo Mountains of British Columbia (BC) and (2) assess the climatological conditions that could explain observed glacier change in the study area.

\section{Study area and previous work}

The Cariboo Mountains are the northernmost range of the Columbia Mountains of BC, Canada (Fig. 1). The climate of the Cariboo Mountains is transitional, wetter than the Rocky Mountains to the east, and drier than the Coast Mountains. Total annual precipitation (1971-2000 climate normals) averages 1014 and $679 \mathrm{~mm}$ on the windward (Barkerville, BC) and lee (McBride, BC) sides of the Cariboo Mountains, and annual temperature averages 1.9 and $4.4{ }^{\circ} \mathrm{C}$, respectively (Environment Canada, 2012).

Annual length change in Castle Creek Glacier in the Cariboo Mountains is more closely related to changes of glaciers in the Coast Mountains than those of the Rocky Mountains (Beedle et al., 2009). Meltwater from the majority of glaciers in the Cariboo Mountains contributes to the Fraser River; however, some glaciers in the Premier Range (a Cariboo Mountains subrange) contribute to the Columbia River (Fig. 1). Maurer et al. (2012) found that glaciers of the Cariboo Mountains nearly reached their Holocene maximum extents around $2.73-2.49 \mathrm{ka}$ and that major retreat of the glaciers did not begin until the early 20th century. Luckman et al. (1987) showed that some glaciers of the Premier Range advanced in the 1960s and 1970s in response to decreased temperatures and increased winter precipitation. Bolch et al. (2010) completed the first satellite inventory of glaciers in western Canada, identifying 536 glaciers in the Cariboo Mountains (2005) with a total surface area of $731 \mathrm{~km}^{2}$. Cariboo Mountains glaciers lost $7.06 \mathrm{~km}^{3}$ of ice at a rate of $-0.58 \mathrm{~m}$ water equivalent (w.e.) $\mathrm{a}^{-1}$ during the period 1985-1999 (Schiefer et al., 2007).

\section{Methods}

\subsection{Imagery and supplemental data}

We measured glacier extent and surface-elevation change from aerial photographs obtained from the British Columbia Government and Canada National Air Photo Library (Table 1). Imagery prior to 2005 was scanned at a resolution of $12-14 \mu \mathrm{m}$ from diapositives or negatives using a photogrammetric scanner, whereas imagery from 2005 was available as digital aerial triangulation (AT) scans (digital photos with available exterior orientation; BC Ministry of Environment, 1998). Ground sampling distance ranges from 0.2 to $1.1 \mathrm{~m}$ depending on scanning resolution and image scale. Most photos were taken in late summer, but dates range from mid-July to late September. We used all images to estimate glacier length and area change, whereas only those from 1946, 1952, 1984, 1985, and 2005 were used to determine surface-elevation change. As photos for each subregion were taken in different years, we thus report a mean area-weighted year: 1952 for photos taken in 1946, 1952, or 1955; 1970 for those of 1967, 1970, or 1971; and 1985 for those of 1984 or 1985. All annual rates of extent or volume change are calculated using the actual duration between images. We report extent change of glaciers within three intervals (1952-1970, 1970-1985, and 1985-2005) and surface-elevation change for two epochs (1952-1985 and 1985-2005).

We use ClimateWNA (Wang et al., 2012) to assess the variability in temperature and precipitation during the periods for which we measure glacier ex- 
Table 1. Aerial photography used to derive glacier extent and thickness change data.

\begin{tabular}{lllrrrll}
\hline Date & Region & Roll ID & \# of Images & Scale & Resolution (m) & Contrast & Snowcover \\
\hline 10 Sep 1946 & C & BC320 & 15 & $1: 31680$ & 0.38 & Poor & Good \\
25 Sep 1952 & C & A13538 & 5 & $1: 60000$ & 0.84 & Fair & Good \\
9 Sep 1952 & Q & A13538 & 5 & $1: 60000$ & 0.84 & Fair & Good \\
30 Aug 1955 & P & A14930 & 7 & $1: 70000$ & 0.98 & Poor & Fair \\
15 Aug 1967 & C & BC7019 & 15 & $1: 15840$ & 0.19 & Good & Fair \\
19 Aug 1970 & P & BC5394 & 5 & $1: 80000$ & 0.96 & Fair & Good \\
15 Jul 1971 & Q & A21587 & 4 & $1: 80000$ & 1.12 & Poor & Fair \\
24 Jul 1977 & C & A24743 & 8 & $1: 70000$ & 0.98 & Poor & Poor \\
31 Jul 1984 & C & BC84073 & 4 & $1: 60000$ & 0.72 & Fair & Fair \\
16 Aug 1985 & Q & BC85071 & 5 & $1: 60000$ & 0.72 & Fair & Fair \\
16 Aug 1985 & Q, P & BC85075 & 7 & $1: 60000$ & 0.72 & Fair & Fair \\
11 Sep 1996 & C & BCB96106 & 6 & $1: 40000$ & 0.48 & Poor & Fair \\
25 Aug 2005 & C & BCC05111 & 10 & $1: 20000$ & 0.24 & Good & Good \\
25 Aug 2005 & P & BCC05108 & 18 & $1: 20000$ & 0.24 & Good & Good \\
25 Aug 2005 & Q, P & BCC05109 & 16 & $1: 20000$ & 0.24 & Good & Good \\
25 Aug 2005 & Q & BCC05110 & 6 & $1: 20000$ & 0.24 & Good & Good \\
\hline
\end{tabular}

Regions: C: Castle Creek, Q: Quanstrom, P: Premier Range. Roll ID: BC: Provincial aerial photos, A: Federal aerial photos. Contrast: Subjective determination of image contrast on a scale from poor to excellent. Snowcover: Subjective determination of snowcover extent. Poor refers to more snowcover.

tent and surface-elevation change. The ClimateWNA v4.72 program (http://www.genetics.forestry.ubc.ca/cfcg/ ClimateWNA/ClimateWNA.html) interpolates and extracts climate data for specific locations for western North America, relying on downscaled PRISM (Daly et al., 2002) and historical data (Mitchell and Jones, 2005) to generate monthly time series of temperature and precipitation. For details, refer to Wang et al. (2012). We use averaged ClimateWNA output for points along the centerline every $100 \mathrm{~m}$ in elevation for all 33 glaciers $(n=212)$ to estimate Cariboo Mountains glacier climatology, and for glaciers of the Castle Creek region $(n=47)$, Quanstrom region $(n=62)$, and Premier region $(n=103)$ to estimate subregional climatology. We compare monthly temperature precipitation data from ClimateWNA with measurements at Castle Creek Glacier (Déry et al., 2010) for 2009-2011 to estimate the ability of ClimateWNA to represent conditions at high elevations in the Cariboo Mountains.

To investigate dominant synoptic patterns over the Cariboo Mountains, we use the National Centers for Environmental Protection/National Center for Atmospheric Research (NCEP/NCAR) reanalysis data (Kalnay et al., 1996) of $700 \mathrm{hPa}$ geopotential height anomalies. The $700 \mathrm{hPa}$ geopotential surface provides a good indicator of general atmospheric conditions in the middle troposphere $(\sim 3000 \mathrm{~m})$, an elevation just above the uppermost extent of most glaciers in the Cariboo Mountains. We assess climatic conditions for balance years (October-September), and for ablation and accumulation seasons, defined as June-September and October-May, respectively.

\subsection{Photogrammetry}

We used the Vr Mapping photogrammetry software suite (Cardinal Systems LLC) to create stereo-models from aerial photos. Exterior orientation for the models was derived from tie points and common ground control points (GCP) horizontally and vertically distributed throughout the photos (Schiefer and Gilbert, 2007; Barrand et al., 2009). Within each subregion we used common GCPs to reduce systematic positional errors (Kääb and Vollmer, 2000; Schiefer and Gilbert, 2007; Schiefer et al., 2007). GCPs consisted of stable bedrock features or boulders obtained from aerial triangulated stereo-models (BC Ministry of Environment, 1998).

Eleven check patches, located on stable surfaces around each glacier region (Fig. 2), were used to quantify the relative accuracy of the stereo-models (Fig. 3). Each check patch is comprised of 25 individual checkpoints in a $5 \mathrm{~m}$ grid; we estimated systematic bias of stereo-models from the mean residuals of the check patches. Trend surfaces were created from these 11 mean residuals and used to apply a correction for glacier surface-elevation measurements.

\subsection{Glacier subset selection}

With the exception of 2005, glaciers of the Cariboo Mountains were not comprehensively photographed in any given year, and we thus concentrate our study on three subregions of the Cariboo Mountains with suitable photographic coverage: (1) the Castle Creek Glacier area, (2) the Mt. Quanstrom area, and (3) the Premier Range (Figs. 1 and 2). We selected our subset of glaciers based on (1) availability of imagery, both in terms of temporal resolution and spatial scale; (2) snow cover and contrast; and (3) representativeness 

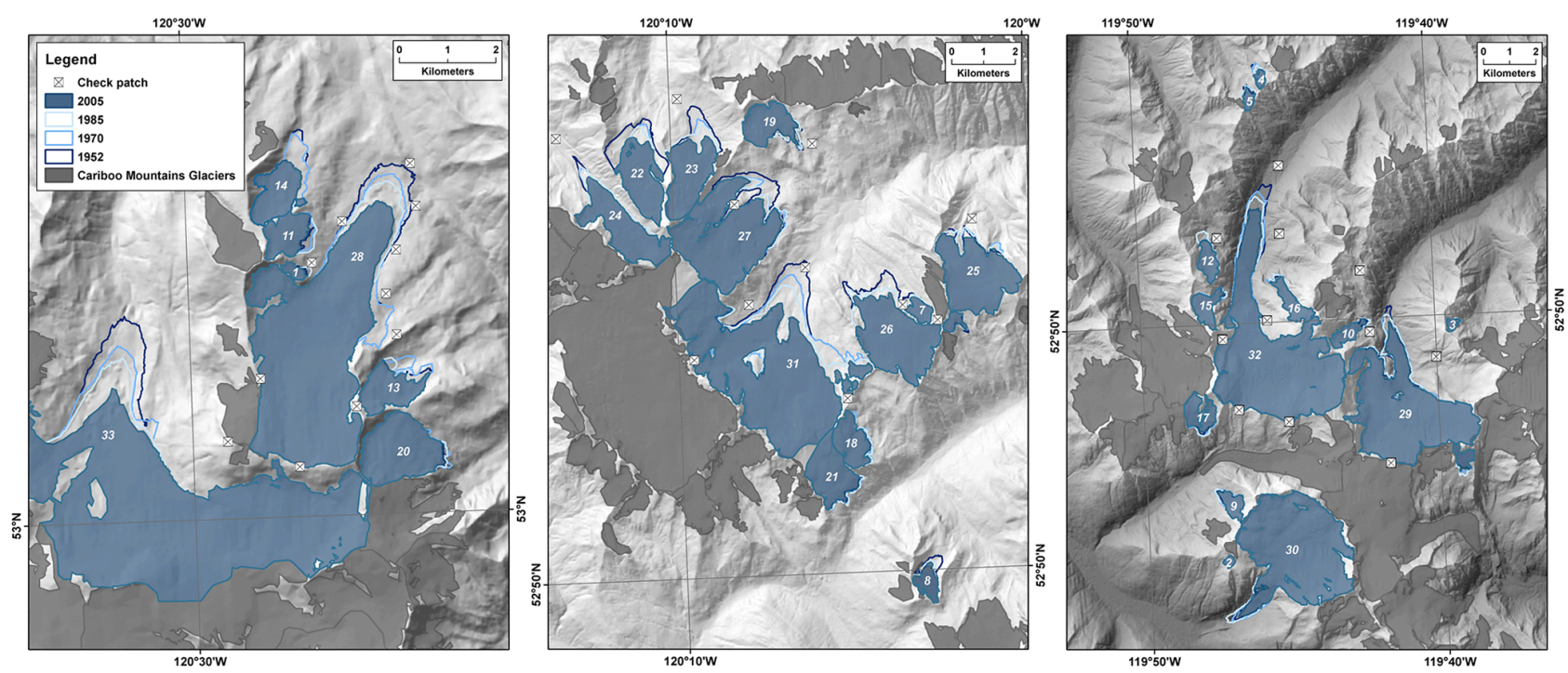

Figure 2. Cariboo Mountains subregions showing subset of 33 glaciers, including extents for 1952, 1970, 1985, and 2005. Panels show from left to right the Castle, Quanstrom, and Premier subregions. Numerical glacier identification, numbered by 2005 surface area from smallest to largest, corresponds to that of Tables 2 and 3.
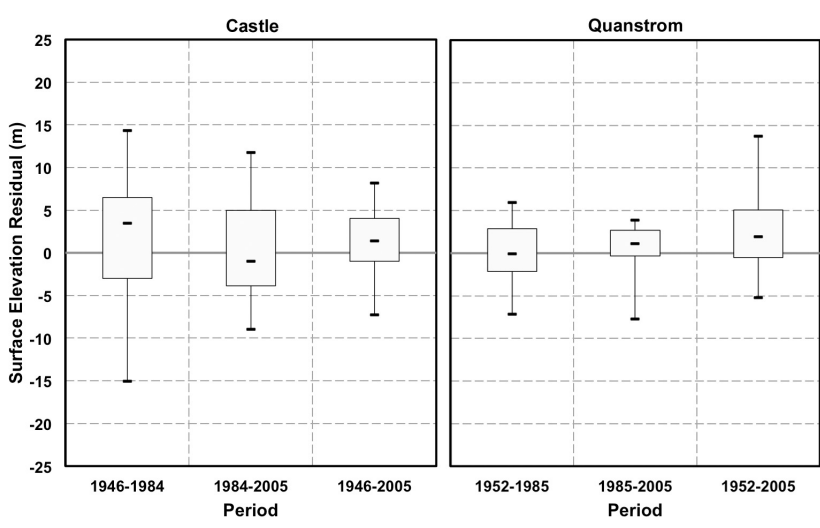

Figure 3. Box-and-whisker plots showing the maximum, interquartile range, median, and minimum of surface-elevation residuals of 275 checkpoints. Checkpoints are used to determine relative accuracy of stereo-models and bias correction for measurement of surface-elevation change of glaciers in the Castle and Quanstrom regions in three periods.

based on average glacier morphometry of Cariboo Mountains glaciers presented in Bolch et al. (2010). Snow cover and poor contrast of older aerial photography reduce potential glaciers for study (Table 1). Sun angle with respect to glacier aspect and slope leads to local areas of high reflectivity and an absence of contrast, particularly for some southfacing glaciers. We omitted glaciers with these issues in our selection of a subset.

Within the three Cariboo Mountains subregions, we selected 33 glaciers representing five size classes $(0.1-0.5,0.5-$ $1.0,1.0-5.0,5.0-10.0$, and $>10.0 \mathrm{~km}^{2}$ ). We used surface area as our primary criterion to select glaciers as many studies find it to be the key morphometric determinant of glacier extent change (e.g., Serandbrei-Barbero et al., 1999; Hoelzle et al., 2003; Paul et al., 2004; Andreassen et al., 2008; Bolch et al., 2010; Paul and Andreassen, 2009). Our analysis oversampled glaciers in the largest size class as these glaciers likely play a dominant role in regional volume change and meltwater contributions to their respective watersheds (e.g., Arendt et al., 2006; DeBeer and Sharp, 2007; Paul and Haeberli, 2008). All ice masses with the exception of Kiwa Glacier (glacier 32 in Fig. 2 and Table 3) are land-terminating glaciers.

\subsection{Data collection and analysis}

We collected glacier extents and point measurements of surface elevation directly from the stereo-models following the methods described elsewhere (Tennant and Menounos, 2013; Beedle et al., 2014). This approach allowed us to collect elevation and points while viewing the 3-D models with polarized glasses and a shutter screen. The primary advantage of this approach is that it minimizes common errors that can occur with automated digital elevation model extraction methods (e.g., pixel mismatch and interpolation errors). Complete glacier outlines were mapped for 2005, and glacier extents were updated for previous years only below the transient snow line (TSL), thus eliminating errantly mapping seasonal snow cover as glacierized area (e.g., Koblet et al., 2010). Delineation of planimetric glacier area above the TSL is problematic as seasonal snow cover masks the glacier margin, and can erroneously inflate estimates of glacier surface area. Mapping of ice divides relied on surface elevation and sur- 
face features such as crevasses and runnels; these divides were held constant in order to compare dimensional changes for a given ice body through time. Extent-change analysis was made for different glacier subsets by epoch based on aerial photo coverage and snow cover. Collectively, our analysis allows us to compare area change for 33 glaciers for the epochs 1952-1985, 1985-2005, and 1952-2005 (33-glacier subset), as well as for 26 glaciers in the additional epochs 1952-1970 and 1970-1985 (26-glacier subset).

Poor contrast and snow cover limit our analysis of glacier surface-elevation change to seven glaciers for the periods 1952-1985, 1985-2005, and 1952-2005. For these glaciers, we measured surface elevation on a $100 \mathrm{~m}$ grid for large glaciers $\left(>1 \mathrm{~km}^{2}\right)$ and on a $50 \mathrm{~m}$ grid for small glaciers $\left(<1 \mathrm{~km}^{2}\right)$. Poor contrast in the earliest photographs inhibited data collection over portions of glacier accumulation zones for four of the seven glaciers. In these areas, we extrapolate from the three highest elevation bins where we have measurements, assigning the average surface-elevation change of these observations to the bins with missing values. This assumption was necessary only for periods that rely on the earliest year of photography (1952); missing data total a maximum of $27 \%$ of total glacier surface area.

To calculate glacier-wide volume change from point measurements, we multiplied average elevation change for each $50 \mathrm{~m}$ elevation bin and summed over the entire glacier surface. Elevation bins and glacier surface were derived from epoch-specific glacier hypsometries created from the same point measurements. Where poor contrast led to an absence of measurements in the accumulation area, we used surface-elevation measurements for that elevation bin from the stereo-model of a prior or subsequent year. This approach assumes that surface elevation and extent underwent negligible change, an assumption that would be inappropriate in the rapidly changing ablation zones, but one that is more likely in the accumulation zones where this assumption was applied. We calculated glacier-wide average thickness change based on the average of the two extents that define a given period (e.g., Arendt et al., 2002; Barrand et al., 2010). All values presented in water equivalent (w.e.) are calculated by assuming a density of $900 \mathrm{~kg} \mathrm{~m}^{-3}$ in the ablation area and $750 \mathrm{~kg} \mathrm{~m}^{-3}$ in the accumulation area (e.g., Huss, 2013; Beedle et al., 2014); ablation and accumulation areas are defined by each glacier's median elevation (Table 2).

To estimate regional (Cariboo Mountains) glacier extent change, we extrapolated from measurements of our subset of studied glaciers using the average rates of relative extent change by size class for different periods. We used two methods to estimate Cariboo Mountains surface-elevation change: first, the average surface-elevation change of our subset of seven glaciers; second, the average gradient of surface-elevation change with elevation, defined as the average of all measurements within each $50 \mathrm{~m}$ bin, and integrated it with the Cariboo Mountains glacier hypsometry of 1985. We compare extrapolated values with results from re- cent work that included volume change (Schiefer et al., 2007) and extent change (Bolch et al., 2010) of Cariboo Mountains glaciers.

\subsection{Error analysis}

We estimated error in glacier extent and extent change based on a buffer approach (Granshaw and Fountain, 2006). Our buffer ( \pm 5 pixels) yields widths of $\sim 5.5$ to $1.3 \mathrm{~m}$, depending on image resolution. Error in extent change is calculated as the root-mean-squared error (RMSE) of the error estimates for the years that define a given period. Average errors for the 33-glacier subset range from 0.8 to $2.4 \%$ for extents, and from 2.3 to $3.6 \%$ for extent change. These errors vary depending on image resolution (see Table 1) and glacier dimensions.

We used the standard deviation of 275 check points in 11 check patches to estimate error in our measurements of surface-elevation change $\left(E_{\Delta Z}\right)$. To account for greater uncertainty over surfaces with reduced contrast, we added an error of $\pm 5 \mathrm{~m}$ for measurements above the TSL. In cases where measurements are absent due to poor contrast, we increased this added error term to $\pm 10 \mathrm{~m}$ (e.g., Tennant and Menounos, 2013). Error in measurements of surface-elevation change in the ablation area is $1 \sigma$ of check points, whereas for the accumulation zone it is the quadrature sum of $1 \sigma$ of check points $\left(E_{1}\right)$ and the added error of \pm 5 or $10 \mathrm{~m}$ for reduced contrast $\left(E_{1}\right)$ :

$E_{\Delta Z}=\sqrt{E_{1}^{2}+E_{2}^{2}}$.

Converting to water equivalent units through density assumptions imparts an additional error term. To estimate error in the density assumption of $750 \mathrm{~kg} \mathrm{~m}^{-3}$ for the accumulation zone, we used a range of possible values for accumulation-zone density $\left(600-900 \mathrm{~kg} \mathrm{~m}^{-3}\right)$. We estimate error in our measurements of surface-elevation change in water-equivalent units $\left(E_{\Delta Z}\right.$ w.e. $)$ as

$E_{\Delta Z \text { w.e. }}=\sqrt{E_{\Delta Z}^{2} \rho^{2}+E_{\rho}^{2} \Delta Z^{2}}$,

where $\rho$ is density expressed as a water-equivalent conversion factor ( 0.9 in the ablation zone, 0.75 in the accumulation zone) and $E_{\rho}$ is the error in our density assumptions, assumed to be 0 in the ablation area and 0.15 in the accumulation zone.

We estimate volume change error $\left(E_{\mathrm{VOL}}\right)$ after Barrand et al. (2010) as

$E_{\mathrm{VOL}}=\sqrt{\sum_{1}^{\text {bin }}\left(E_{\mathrm{bin}} A_{\mathrm{bin}}\right)}$,

where $E_{\text {bin }}$ is the error $\left(E_{\Delta Z \text { w.e. }}\right)$ and $A_{\text {bin }}$ is the surface area of each $50 \mathrm{~m}$ bin.

Previous work indicated a spatial correlation of $1000 \mathrm{~m}$ in photogrammetric DEMs (Rolstad et al., 2009), and others 
Table 2. Morphometric properties of the 33-glacier subset.

\begin{tabular}{|c|c|c|c|c|c|c|c|c|c|c|}
\hline $\begin{array}{l}\text { Id } \\
\text { (Name) }\end{array}$ & Region & $\begin{array}{r}\text { Length } \\
\text { (m) }\end{array}$ & $\begin{array}{r}\text { Area } \\
\left(\mathrm{km}^{2}\right)\end{array}$ & Slope & Aspect & $\begin{array}{l}\text { Mean } \\
Z(\mathrm{~m})\end{array}$ & $\begin{array}{r}\text { Median } \\
Z(\mathrm{~m})\end{array}$ & $\begin{array}{r}\text { Min. } \\
Z \text { (m) }\end{array}$ & $\begin{array}{l}\text { Max. } \\
Z(\mathrm{~m})\end{array}$ & $\begin{array}{l}\text { Range } \\
Z \text { (m) }\end{array}$ \\
\hline 1 & C & 513 & 0.109 & 22.7 & E & 2472 & 2471 & 2360 & 2590 & 230 \\
\hline 2 & $\mathrm{P}$ & 452 & 0.135 & 19.5 & W & 2587 & 2593 & 2469 & 2682 & 213 \\
\hline 3 & $\mathrm{P}$ & 641 & 0.155 & 27.5 & $\mathrm{NE}$ & 2607 & 2619 & 2413 & 2785 & 372 \\
\hline 4 & $\mathrm{P}$ & 779 & 0.210 & 18.0 & $\mathrm{~N}$ & 2485 & 2480 & 2379 & 2651 & 272 \\
\hline 5 & $\mathrm{P}$ & 922 & 0.264 & 21.1 & $\mathrm{~N}$ & 2523 & 2528 & 2324 & 2718 & 394 \\
\hline 6 & Q & 731 & 0.276 & 22.2 & SE & 2532 & 2545 & 2256 & 2692 & 436 \\
\hline 7 & Q & 952 & 0.422 & 21.3 & NW & 2386 & 2383 & 2228 & 2621 & 393 \\
\hline 8 & Q & 1366 & 0.563 & 18.3 & $\mathrm{~N}$ & 2283 & 2279 & 2093 & 2494 & 401 \\
\hline 9 & $\mathrm{P}$ & 1386 & 0.648 & 25.7 & NW & 2420 & 2415 & 2117 & 2968 & 851 \\
\hline 10 & $\mathrm{P}$ & 1552 & 0.650 & 26.6 & $\mathrm{NE}$ & 2406 & 2400 & 1990 & 2751 & 761 \\
\hline 11 & C & 1173 & 0.653 & 21.2 & SE & 2452 & 2445 & 2246 & 2733 & 487 \\
\hline 12 & $\mathrm{P}$ & 1671 & 0.830 & 21.6 & $\mathrm{~N}$ & 2399 & 2407 & 2169 & 2646 & 477 \\
\hline 13 & C & 1017 & 0.860 & 20.7 & NE & 2363 & 2343 & 2135 & 2720 & 585 \\
\hline 14 & $\mathrm{C}$ & 1419 & 0.913 & 16.2 & NE & 2322 & 2314 & 2175 & 2580 & 405 \\
\hline 15 & $\mathrm{P}$ & 1327 & 0.983 & 23.8 & $\mathrm{NE}$ & 2665 & 2662 & 2248 & 3157 & 909 \\
\hline 16 & $\mathrm{P}$ & 2027 & 0.995 & 24.5 & NW & 2699 & 2716 & 2171 & 3093 & 922 \\
\hline 17 & $\mathrm{P}$ & 1584 & 1.145 & 26.7 & $\mathrm{~S}$ & 2728 & 2724 & 2313 & 3188 & 875 \\
\hline 18 & Q & 1209 & 1.349 & 16.7 & E & 2362 & 2364 & 2172 & 2515 & 343 \\
\hline 19 & Q & 2199 & 1.609 & 10.8 & SE & 2469 & 2478 & 2187 & 2633 & 446 \\
\hline 20 & C & 1870 & 1.816 & 18.5 & E & 2387 & 2398 & 2044 & 2749 & 705 \\
\hline 21 & Q & 1796 & 2.188 & 15.7 & $\mathrm{~S}$ & 2421 & 2449 & 2052 & 2669 & 617 \\
\hline 22 & Q & 2965 & 2.464 & 12.3 & $\mathrm{~N}$ & 2438 & 2436 & 2198 & 2803 & 605 \\
\hline 23 & Q & 3002 & 2.655 & 18.5 & $\mathrm{~N}$ & 2482 & 2490 & 2054 & 3019 & 965 \\
\hline 24 & Q & 3562 & 3.049 & 17.3 & NW & 2352 & 2359 & 1991 & 2789 & 798 \\
\hline 25 & Q & 2300 & 4.280 & 14.9 & $\mathrm{~N}$ & 2463 & 2488 & 2061 & 2752 & 691 \\
\hline 26 & Q & 3294 & 4.625 & 11.9 & NW & 2417 & 2425 & 2137 & 2708 & 571 \\
\hline 27 & Q & 3062 & 7.037 & 12.8 & $\mathrm{NE}$ & 2416 & 2408 & 2056 & 2917 & 861 \\
\hline 28 (Castle Creek) & $\mathrm{C}$ & 5875 & 9.645 & 11.1 & NE & 2387 & 2397 & 1881 & 2827 & 946 \\
\hline 29 (Tête) & $\mathrm{P}$ & 5971 & 12.674 & 16.9 & $\mathrm{~N}$ & 2520 & 2565 & 1649 & 3357 & 1708 \\
\hline 30 (David) & $\mathrm{P}$ & 5228 & 13.533 & 19.3 & SW & 2609 & 2616 & 1352 & 3339 & 1987 \\
\hline 31 & Q & 4010 & 14.782 & 13.2 & $\mathrm{NE}$ & 2319 & 2334 & 1868 & 2745 & 877 \\
\hline 32 (Kiwa) & $\mathrm{P}$ & 9597 & 17.154 & 17.2 & $\mathrm{~N}$ & 2617 & 2705 & 1491 & 3509 & 2018 \\
\hline 33 & $\mathrm{C}$ & 7302 & 19.094 & 12.8 & $\mathrm{~N}$ & 2273 & 2288 & 1803 & 2910 & 1107 \\
\hline
\end{tabular}

Slope and elevation data from TRIM DEM and 2005 extent. Length and area data from 2005 extent.

have calculated a number of independent measurements $(n)$ assuming a correlation scale of $1000 \mathrm{~m}$ (Barrand et al., 2010). We calculated degrees of freedom for each glacier from point measurements of surface-elevation change in epochs with complete spatial coverage. Using the Incremental Spatial Autocorrelation tool in ArcGIS 10.1, we calculated correlation distances that range from 350 to $2000 \mathrm{~m}$, yielding effective degrees of freedom that range from 1 to 5 .

We used cross-validation to test the accuracy of our extrapolation of Cariboo Mountains glacier extent and surfaceelevation change. In our test of glacier extent extrapolation, we partitioned the 26-glacier subset into four scenarios where we withheld 75,50 , and $25 \%$ of the individual glaciers as a validation set and retained the remainder as a training set. Set selection was randomized within each size class, ensuring each set retained glaciers of varying size. Each of the three scenarios was applied to observations in five epochs: 1952-1970, 1970-1985, 1985-2005, 1952-1985, and 19522005. We used the standard deviation of these 15 test cases $( \pm 4.7 \%)$ as an estimate of error in our extrapolation of the extent of all Cariboo Mountains glaciers. To estimate error in our extrapolation of surface-elevation change, we parti- tioned our seven glacier subset into two scenarios where we withheld three and four individual glaciers as a validation set and retain the remainder as a training set. Each scenario was applied to observations in three epochs: 1952-1985, 19852005, and 1952-2005. We used the variability of these six test cases to estimate error in our extrapolation of surfaceelevation change by means of two methods: (1) mean annual rate of surface-elevation change in the glacier subset $\left( \pm 0.077 \mathrm{~m}\right.$ w.e. $\left.\mathrm{a}^{-1}\right)$ and (2) mean surface-elevation change within each collective $50 \mathrm{~m}$ elevation bin for the glacier subset $\left( \pm 0.089\right.$ m w.e. $\left.\mathrm{a}^{-1}\right)$.

\section{Results}

\subsection{Regional representativeness}

As expected, our glacier subset undersamples ice masses of the Cariboo Mountains in all size classes except the largest size class (Fig. 4). Most glaciers in the Cariboo Mountains (40\%) fall in the $1.0-5.0 \mathrm{~km}^{2}$ size class compared to $20 \%$ in our sample. In contrast, our subset contains $61 \%$ glaciers exceeding $5.0 \mathrm{~km}^{2}$, compared to $21 \%$ for the Cariboo Moun- 
Table 3. Glacier extent and area change data for glaciers and summed by subregion and size class.

\begin{tabular}{|c|c|c|c|c|c|c|c|c|c|c|c|c|c|c|c|}
\hline \multirow[b]{2}{*}{ Id } & \multicolumn{3}{|c|}{ Extent } & \multicolumn{6}{|c|}{ Successive periods } & \multicolumn{6}{|c|}{ Cumulative periods } \\
\hline & Region & $\begin{array}{r}\text { Area } \\
1952 \\
\left(\mathrm{~km}^{2}\right)\end{array}$ & $\begin{array}{r}\text { Area } \\
1970 \\
\left(\mathrm{~km}^{2}\right)\end{array}$ & $\begin{array}{r}\text { Area } \\
1985 \\
\left(\mathrm{~km}^{2}\right)\end{array}$ & $\begin{array}{r}\text { Area } \\
2005 \\
\left(\mathrm{~km}^{2}\right)\end{array}$ & $\begin{array}{l}\text { Area change } \\
52-70\left(\mathrm{~km}^{2}\right)\end{array}$ & $\begin{array}{l}\text { Area change } \\
52-70(\%)\end{array}$ & $\begin{array}{l}\text { Area change } \\
70-85\left(\mathrm{~km}^{2}\right)\end{array}$ & $\begin{array}{r}\text { Area change } \\
70-85(\%)\end{array}$ & $\begin{array}{l}\text { Area change } \\
85-05\left(\mathrm{~km}^{2}\right)\end{array}$ & $\begin{array}{r}\text { Area change } \\
85-05(\%)\end{array}$ & $\begin{array}{l}\text { Area change } \\
52-85\left(\mathrm{~km}^{2}\right)\end{array}$ & $\begin{array}{r}\text { Area change } \\
52-85(\%)\end{array}$ & $\begin{array}{l}\text { Area Change } \\
52-05\left(\mathrm{~km}^{2}\right)\end{array}$ & $\begin{array}{r}\text { Area change } \\
52-05(\%)\end{array}$ \\
\hline 1 & $\mathrm{C}$ & 0.117 & No data & 0.131 & 0.109 & No data & No data & No data & No data & -0.022 & -16.8 & 0.014 & 12.0 & -0.008 & -6.8 \\
\hline 2 & P & 0.137 & No data & 0.136 & 0.135 & No data & No data & No data & No data & -0.001 & -0.7 & -0.001 & -0.7 & -0.002 & -1.5 \\
\hline 3 & P & 0.157 & 0.158 & 0.161 & 0.155 & 0.001 & 0.6 & 0.003 & 1.9 & -0.006 & -3.7 & 0.004 & 2.5 & -0.002 & -1.3 \\
\hline 4 & P & 0.301 & 0.298 & 0.269 & 0.210 & -0.003 & -1.0 & -0.029 & -9.7 & -0.059 & -21.9 & -0.032 & -10.6 & -0.091 & -30.2 \\
\hline 5 & P & 0.283 & 0.310 & 0.303 & 0.264 & 0.027 & 9.5 & -0.007 & -2.3 & -0.039 & -12.9 & 0.020 & 7.1 & -0.019 & -6.7 \\
\hline 6 & Q & 0.284 & No data & 0.291 & 0.276 & No data & No data & No data & No data & -0.015 & -5.2 & 0.007 & 2.5 & -0.008 & -2.8 \\
\hline 7 & $\mathrm{Q}$ & 0.536 & No data & 0.478 & 0.422 & No data & No data & No data & No data & -0.056 & -11.7 & -0.058 & -10.8 & -0.114 & -21.3 \\
\hline 8 & Q & 0.775 & No data & 0.626 & 0.563 & No data & No data & No data & No data & -0.063 & -10.1 & -0.149 & -19.2 & -0.212 & -27.4 \\
\hline 9 & $P$ & 0.662 & 0.728 & 0.709 & 0.648 & 0.066 & 10.0 & -0.019 & -2.6 & -0.061 & -8.6 & 0.047 & 7.1 & -0.014 & -2.1 \\
\hline 10 & P & 0.665 & 0.700 & 0.707 & 0.650 & 0.035 & 5.3 & 0.007 & 1.0 & -0.057 & -8.1 & 0.042 & 6.3 & -0.015 & -2.3 \\
\hline 11 & $\mathrm{C}$ & 0.682 & 0.746 & 0.785 & 0.653 & 0.064 & 9.4 & 0.039 & 5.2 & -0.132 & -16.8 & 0.103 & 15.1 & -0.029 & -4.3 \\
\hline 12 & P & 0.853 & 0.858 & 0.991 & 0.830 & 0.005 & 0.6 & $\mathbf{0 . 1 3 3}$ & 15.5 & -0.161 & -16.2 & 0.138 & 16.2 & -0.023 & -2.7 \\
\hline 13 & $\mathrm{C}$ & 1.070 & 1.109 & 0.918 & 0.860 & 0.039 & 3.6 & -0.191 & -17.2 & -0.058 & -6.3 & -0.152 & -14.2 & -0.210 & -19.6 \\
\hline 14 & $\mathrm{C}$ & 1.272 & 1.235 & No data & 0.913 & -0.037 & -2.9 & No data & No data & No data & No data & No data & No data & -0.359 & -28.2 \\
\hline 15 & $\mathrm{P}$ & 1.003 & 1.030 & 1.012 & 0.983 & 0.027 & 2.7 & -0.018 & -1.7 & -0.029 & -2.9 & 0.009 & 0.9 & -0.020 & -2.0 \\
\hline 16 & P & 1.056 & 1.093 & 1.074 & 0.995 & 0.037 & 3.5 & -0.019 & -1.7 & -0.079 & -7.4 & 0.018 & 1.7 & -0.061 & -5.8 \\
\hline 17 & P & 1.166 & 1.244 & 1.235 & 1.145 & 0.078 & 6.7 & -0.009 & -0.7 & -0.090 & -7.3 & 0.069 & 5.9 & -0.021 & -1.8 \\
\hline 18 & Q & 1.432 & 1.436 & 1.444 & 1.349 & 0.004 & 0.3 & 0.008 & 0.6 & -0.095 & -6.6 & 0.012 & 0.8 & -0.083 & -5.8 \\
\hline 19 & Q & 1.767 & 1.759 & 1.757 & 1.609 & -0.008 & -0.5 & -0.002 & -0.1 & -0.148 & -8.4 & -0.010 & -0.6 & -0.158 & -8.9 \\
\hline 20 & C & 1.833 & 1.874 & 1.854 & 1.816 & 0.041 & 2.2 & -0.020 & -1.1 & -0.038 & -2.0 & 0.021 & 1.1 & -0.017 & -0.9 \\
\hline 21 & Q & 2.199 & 2.248 & 2.287 & 2.188 & 0.049 & 2.2 & 0.039 & 1.7 & -0.099 & -4.3 & 0.088 & 4.0 & -0.011 & -0.5 \\
\hline 22 & Q & 3.609 & 2.771 & 2.702 & 2.464 & -0.838 & -23.2 & -0.069 & -2.5 & -0.238 & -8.8 & -0.907 & -25.1 & -1.145 & -31.7 \\
\hline 23 & $\mathrm{Q}$ & 3.464 & 3.154 & 3.068 & 2.655 & -0.310 & -8.9 & -0.086 & -2.7 & -0.413 & -13.5 & -0.396 & -11.4 & -0.809 & -23.4 \\
\hline 24 & Q & 3.393 & 3.317 & 3.323 & 3.049 & -0.076 & -2.2 & 0.006 & 0.2 & -0.274 & -8.2 & -0.070 & -2.1 & -0.344 & -10.1 \\
\hline 25 & Q & 4.440 & 4.582 & 4.555 & 4.280 & 0.142 & 3.2 & -0.027 & -0.6 & -0.275 & -6.0 & 0.115 & 2.6 & -0.160 & -3.6 \\
\hline 26 & $\mathrm{Q}$ & 5.584 & No data & 5.156 & 4.625 & No data & No data & No data & No data & -0.531 & -10.3 & -0.428 & -7.7 & -0.959 & -17.2 \\
\hline 27 & $\mathrm{Q}$ & 8.119 & 7.428 & 7.424 & 7.037 & -0.691 & -8.5 & -0.004 & -0.1 & -0.387 & -5.2 & -0.695 & -8.6 & -1.082 & -13.3 \\
\hline 28 & $\mathrm{C}$ & 11.257 & 10.838 & 10.206 & 9.645 & -0.419 & -3.7 & -0.632 & -5.8 & -0.561 & -5.5 & -1.051 & -9.3 & -1.612 & -14.3 \\
\hline 29 & $\mathrm{P}$ & 13.296 & 13.303 & 13.253 & 12.674 & 0.007 & 0.1 & -0.050 & -0.4 & -0.579 & -4.4 & -0.043 & -0.3 & -0.622 & -4.7 \\
\hline 30 & $\mathrm{P}$ & 13.711 & 13.821 & 13.894 & 13.533 & 0.110 & 0.8 & 0.073 & 0.5 & -0.361 & -2.6 & 0.183 & 1.3 & -0.178 & -1.3 \\
\hline 31 & Q & 18.592 & 17.688 & 16.796 & 14.782 & -4.9 & -0.892 & -5.0 & -2.014 & -12.0 & -1.796 & -9.7 & -3.810 & -20.5 & \\
\hline 32 & $P$ & 18.234 & 18.042 & 17.661 & 17.154 & -0.192 & -1.1 & -0.381 & -2.1 & -0.507 & -2.9 & -0.573 & -3.1 & -1.080 & -5.9 \\
\hline \multirow[t]{10}{*}{33} & $\mathrm{C}$ & 21.283 & 20.446 & 20.038 & 19.094 & -0.837 & -3.9 & -0.408 & -2.0 & -0.944 & -4.7 & -1.245 & -5.8 & -2.189 & -10.3 \\
\hline & All & 141.960 & No data & 135.244 & 126.852 & No data & No data & No data & No data & -8.392 & -6.2 & -6.716 & -4.7 & -15.108 & -10.6 \\
\hline & $\mathrm{C}$ & 36.125 & 35.013 & 33.801 & 32.068 & -1.112 & -3.1 & -1.212 & -3.5 & -1.733 & -5.1 & -2.324 & -6.4 & -4.057 & -11.2 \\
\hline & $Q$ & 54.194 & No data & 49.907 & 45.299 & No data & No data & No data & No data & -4.608 & -9.2 & -4.287 & -7.9 & -8.895 & -16.4 \\
\hline & $\mathrm{P}$ & 51.387 & 51.585 & 51.269 & 49.241 & 0.198 & 0.4 & -0.316 & -0.6 & -2.028 & -4.0 & -0.118 & -0.2 & -2.146 & -4.2 \\
\hline & $0.1-0.5 \mathrm{~km}^{2}$ & 1.815 & No data & 1.769 & 1.571 & No data & No data & No data & No data & -0.198 & -11.2 & -0.046 & -2.5 & -0.244 & -13.4 \\
\hline & $0.5-1.0 \mathrm{~km}^{2}$ & 5.991 & 6.264 & 6.196 & 5.619 & 0.273 & 4.6 & -0.068 & -1.1 & -0.577 & -9.3 & 0.205 & 3.4 & -0.372 & -6.2 \\
\hline & $1.0-5.0 \mathrm{~km}^{2}$ & 23.303 & 22.385 & 22.225 & 20.555 & -0.918 & -3.9 & -0.160 & -0.7 & -1.670 & -7.5 & -1.078 & -4.6 & -2.748 & -11.8 \\
\hline & $5.0-10 \mathrm{~km}^{2}$ & 19.376 & 18.266 & 17.630 & 16.682 & -1.110 & -5.7 & -0.636 & -3.5 & -0.948 & -5.4 & -1.746 & -9.0 & -2.694 & -13.9 \\
\hline & $10-50 \mathrm{~km}^{2}$ & 85.116 & 83.300 & 81.642 & 77.237 & -1.816 & -2.1 & -1.658 & -2.0 & -4.405 & -5.4 & -3.474 & -4.1 & -7.879 & -9.3 \\
\hline
\end{tabular}

Values in bold indicate glacier advance,
$1.0-5.0$ none, $5.0-10$ : none, $10-50$ : none.

tains. Eliminating 4 of the 5 largest glaciers from our 33glacier subset (glaciers 30-33; Table 3) would result in a size-class distribution that is nearly identical to glaciers in the Cariboo Mountains.

Our glacier subset also oversamples higher elevations (Fig. 5). Area-altitude distribution of glaciers in the Premier Range, for example, is higher than the average elevation of glaciers in the Cariboo Mountains, whereas the hypsometry of our glacier subset from the Castle and Quanstrom areas are more similar to the total glacierized area of the Cariboo Mountains.

Glaciers in our study also more commonly face north, northeast, and southwest (Fig. 6). Cariboo Mountains glaciers have an average slope of $21.1^{\circ}$, whereas our subset has an average slope of $18.7^{\circ}$; these differences, however, are not statistically significant.

\subsection{Extent change}

Between 1952 and 2005, glaciers lost $15.11 \pm 1.89 \mathrm{~km}^{2}$ $(-10.6 \pm 2.9 \%)$ of their surface area (Table 3). Relative area change varied by subregion, with losses of $-11.2 \pm 2.7 \%$, $-16.4 \pm 2.0 \%$, and $-4.2 \pm 3.9 \%$ for the Castle, Quanstrom, and Premier regions, respectively. Absolute area change by

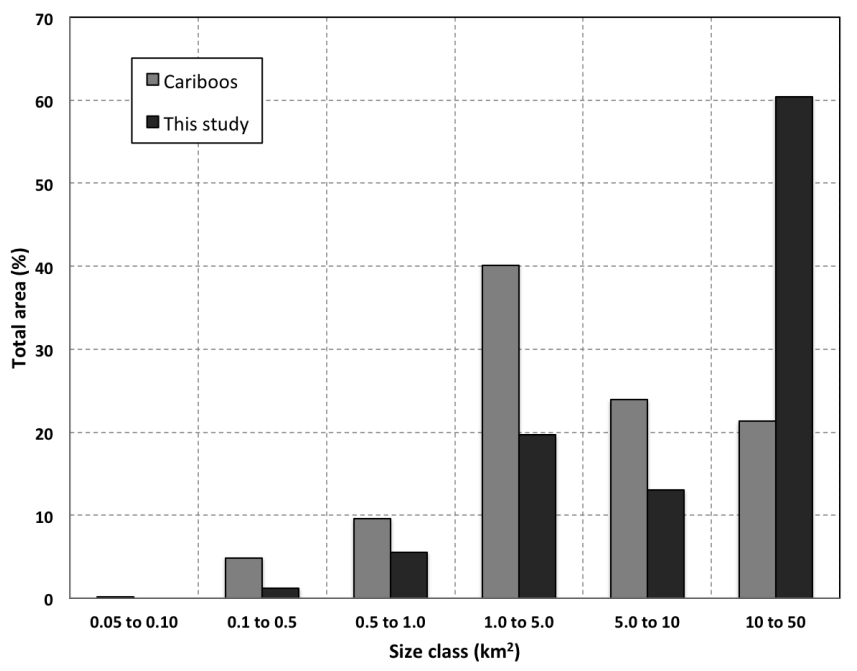

Figure 4. Fraction of total glacierized extent by size class for all Cariboo Mountains glaciers (gray) and this study (black). 


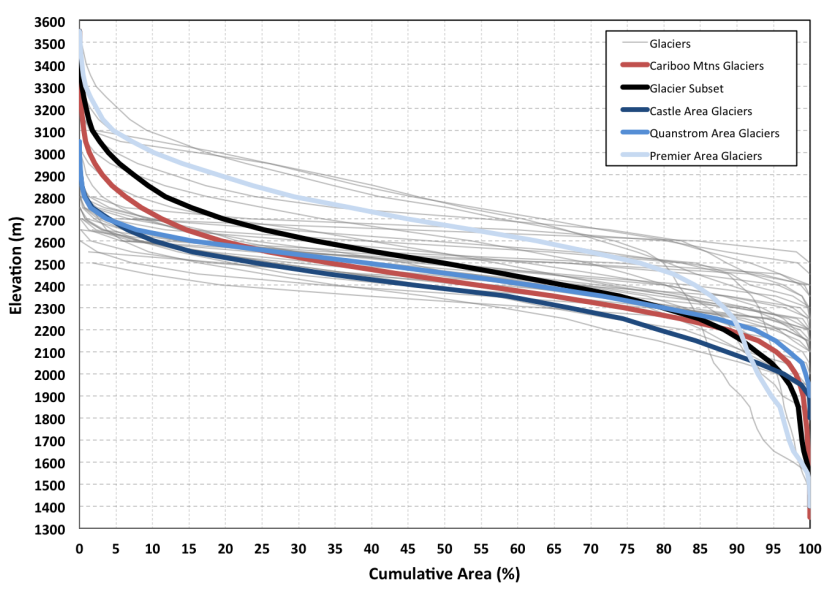

Figure 5. Hypsometries for our subset of glaciers (gray); average subset hypsometry (black); all Cariboo Mountains glaciers (red); and the Castle, Quanstrom, and Premier subregions (darker to lighter blue, respectively).

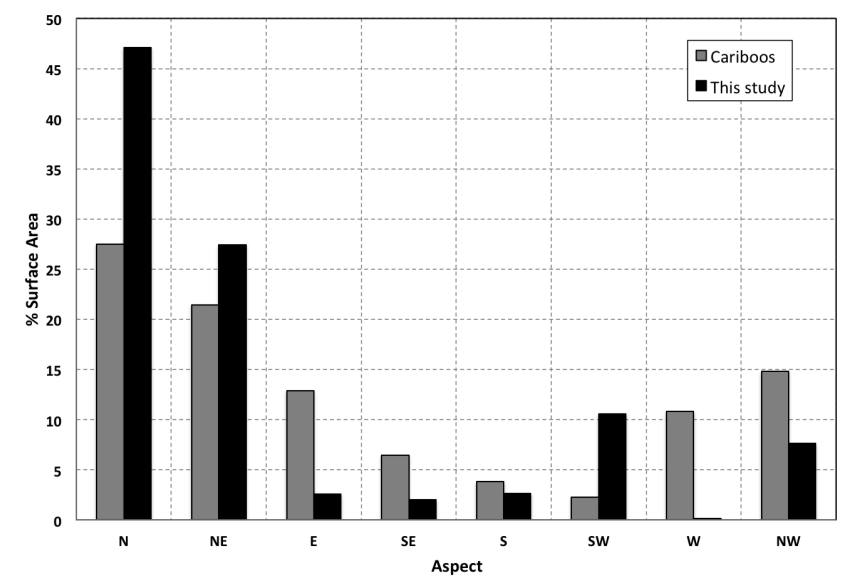

Figure 6. Fraction of total surface by aspect for all Cariboo Mountains glaciers (black) and our subset (gray).

size class over the same period varied from $-6.2 \pm 3.3 \%$ $\left(0.5-1.0 \mathrm{~km}^{2}\right)$ to $-13.9 \pm 1.1 \%\left(5.0-10 \mathrm{~km}^{2}\right)$. Individual glacier area loss varied from $-0.5 \pm 1.6$ to $-31.7 \pm 1.4 \%$. Recession for 22 of the 33 glaciers exceeded the uncertainties in the data. Absolute extent change is dominated by three of the largest glaciers (glaciers 28, 31, and 33), which comprise $50 \%$ of the total subset extent change for the period.

While glaciers on average shrank during the period 19522005, their change during intervening epochs was more complex (Table 3 and Fig. 7). Over the period 1952-1970, for example, 5 of 26 glaciers advanced, 7 receded, and 14 did not significantly change. Between the years 1970 and 1985, 2 of 26 glaciers advanced, 8 shrank, and the area of 16 glaciers did not change. For the cumulative period 1952-1985 nine glaciers advanced, 12 receded, and 11 had no discernable extent change.

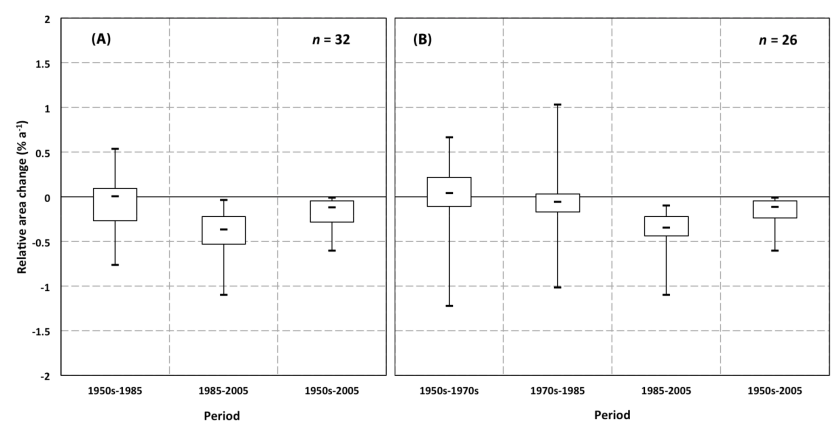

Figure 7. Box-and-whisker plots displaying maximum, interquartile range, median, and minimum of average annual rates of relative area change for (a) 32 glaciers for three periods and (b) for 26 individual glaciers for four periods.

Glaciers that advanced were generally shorter, smaller, steeper, and had higher median and minimum elevations than glaciers that receded (Table 4). Glaciers that negligibly changed tended to be steep, but were longer than those glaciers that advanced. Glaciers that changed little were also higher and flowed over a greater elevation range than advancing ones. Receding glaciers all had northerly aspects, whereas those that advanced or did not change had no dominant aspect.

After 1985, all glaciers throughout the region shrank (Fig. 7). The average rate of area change increased from $-0.05 \pm 0.10 \% \mathrm{a}^{-1}$ between 1952 and 1985 to $-0.41 \pm 0.12 \% \mathrm{a}^{-1}$ between 1985 and 2005. Rates of area change averaged $+0.03 \pm 0.18 \% \mathrm{a}^{-1}$ for $1952-1970$, $-0.08 \pm 0.13 \% \mathrm{a}^{-1}$ for $1970-1985$, and $-0.40 \pm 0.10 \% \mathrm{a}^{-1}$ from 1985 to 2005 . During the period 1985-2005, 30 glaciers receded, and the area of two glaciers did not change. Total surface area change in the period 1985-2005 was $-8.39 \pm 1.51 \mathrm{~km}^{2}$, or $-6.2 \pm 2.3 \%$ (Table 3 ).

Extrapolating from the Bolch et al. (2010) inventory of $2005\left(731 \mathrm{~km}^{2}\right)$ using relative area change of our 26-glacier subset and based on area loss per size class, we estimated that in 1952, the Cariboo Mountains contained a glacierized area of $824 \pm 39 \mathrm{~km}^{2}$. By 1970, glacier cover declined to $805 \pm 38 \mathrm{~km}^{2}$, and continued to shrink to $785 \pm 37 \mathrm{~km}^{2}$ by 1985.

We directly compare glacier extent and extent change (1985-2005) for 28 glaciers common to the Bolch et al. (2010) inventory and this study (Fig. 8). The Bolch et al. inventory relies on glacier extents mapped by the British Columbia Government Terrain Resource Inventory Management (TRIM) program from 1980s aerial photography and Landsat imagery from 2003 to 2007. The 2005 extents of this inventory, created through a semi-automated process, average $2 \%$ larger than our extents manually digitized from aerial photographs with much higher resolution. However, the Bolch et al. (2010) inventory uses an area-weighted date (2005); the actual date of imagery covering the Cari- 
Table 4. Median glacier morphometry for glaciers that underwent some advance, receded continuously, or exhibited no discernable change during the period 1952-1985.

\begin{tabular}{lrrrrrrrr}
\hline & Count & $\begin{array}{r}\text { Length } \\
(\mathrm{m})\end{array}$ & $\begin{array}{r}\text { Area } \\
\left(\mathrm{km}^{2}\right)\end{array}$ & Slope & $\begin{array}{r}\text { Median } \\
\mathrm{Z}(\mathrm{m})\end{array}$ & $\begin{array}{r}\text { Min. } \\
\mathrm{Z}(\mathrm{m})\end{array}$ & $\begin{array}{r}\text { Max. } \\
\mathrm{Z}(\mathrm{m})\end{array}$ & $\begin{array}{r}\text { Range } \\
\mathrm{Z}(\mathrm{m})\end{array}$ \\
\hline Advance & 9 & 1552 & 0.653 & 21.6 & 2449 & 2169 & 2733 & 617 \\
Retreat & 12 & 3032 & 3.640 & 15.2 & 2403 & 2075 & 2774 & 733 \\
No Change & 11 & 1949 & 1.406 & 20.8 & 2605 & 2210 & 2941 & 794 \\
\hline
\end{tabular}

Table 5. Correlation table (Pearson-product moment) of relations of glacier area change with respect to glacier morphometry for three periods.

\begin{tabular}{llrrrrrrr}
\hline & Length & Area & Slope & Median Z & Min. Z & Max. Z & Range \\
\hline $1952-1985$ & Absolute Area Change & $\mathbf{- 0 . 5 5 6}$ & $\mathbf{- 0 . 6 5 0}$ & $\mathbf{0 . 5 9 8}$ & $\mathbf{0 . 3 5 8}$ & 0.322 & -0.065 & -0.215 \\
$1952-1985$ & Relative Area Change & -0.235 & -0.210 & $\mathbf{0 . 5 1 8}$ & 0.323 & 0.135 & 0.053 & -0.046 \\
$1985-2005$ & Absolute Area Change & $-\mathbf{0 . 5 9 6}$ & $-\mathbf{0 . 7 6 5}$ & $\mathbf{0 . 5 2 3}$ & 0.260 & $\mathbf{0 . 5 1 3}$ & -0.193 & $-\mathbf{0 . 3 9 3}$ \\
$1985-2005$ & Relative Area Change & 0.328 & 0.316 & -0.060 & 0.282 & $\mathbf{- 0 . 3 6 4}$ & $\mathbf{0 . 4 1 2}$ & $\mathbf{0 . 4 3 1}$ \\
$1952-2005$ & Absolute Area Change & $\mathbf{- 0 . 5 9 7}$ & $\mathbf{- 0 . 7 3 1}$ & $\mathbf{0 . 5 8 2}$ & 0.312 & $\mathbf{0 . 4 2 7}$ & -0.131 & -0.309 \\
$1952-2005$ & Relative Area Change & -0.008 & 0.011 & $\mathbf{0 . 4 4 0}$ & $\mathbf{0 . 4 8 7}$ & -0.087 & 0.310 & 0.221 \\
\hline
\end{tabular}

Correlation coefficients in bold are significant $(p<0.05) . n=32$ for the periods 1950 s-1985 and 1985-2005. $n=33$ for the period 1950 s -2005 .

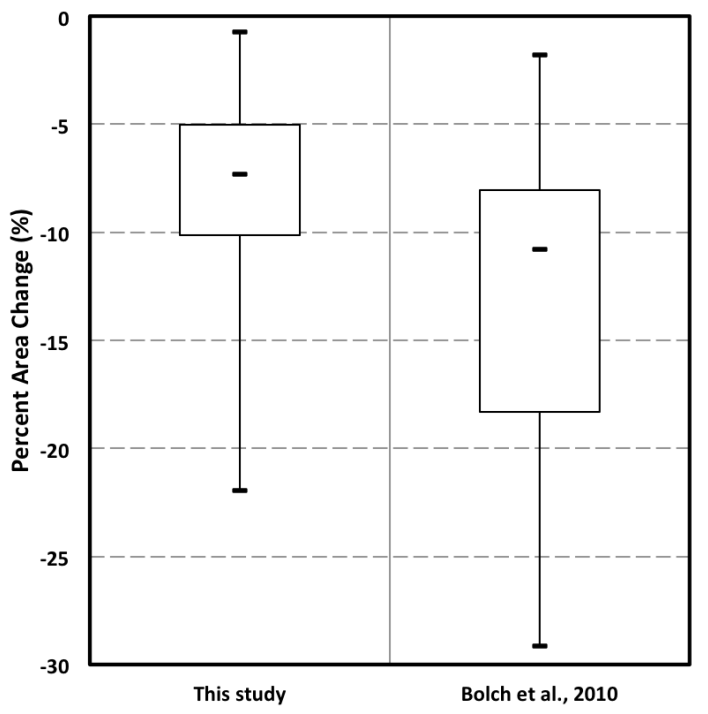

Figure 8. Box-and-whisker plots showing the maximum, interquartile range, median, and minimum percent area change for 28 glaciers from 1985 to 2005 for this study and that of Bolch et al. (2010).

boo Mountains is from 2006. Relative area change for the period 1985-2005 averaged $\sim 0.3 \% \mathrm{a}^{-1}$ for this 28 -glacier subset, and thus the Bolch et al. (2010) inventory, based on 2006 imagery, will not significantly differ from our measurements from 2005 aerial photos. This provides evidence of the quality of the 2005 inventory and the precision of the method used by Bolch et al. (2010). The 1985 TRIM extents, however, digitized manually by the province of British Columbia from the same aerial photographs we use here, average $5 \%$ larger than our extents. Late-lying snow is prevalent in the 1984 and 1985 photographs, but reference to additional photographs in years with a higher snow line helped us distinguish snowfields from glacierized area. The TRIM mapping included some late-lying snow as glacier, resulting in overestimation of 1985 extents in the TRIM data set, by approximately $5 \%$, and thus led to more surface-area loss reported in the Bolch et al. (2010) inventory than we find for the 28 glaciers of this comparison. However, the average change that we observe during the epoch 1985-2005 for our study and that of Bolch et al. (2010) is not statistically different.

Based on the extrapolation procedure described above, we estimate a net change of $-53 \mathrm{~km}^{2}(-6.8 \%)$ for the period 1985-2005 compared to $-114 \mathrm{~km}^{2}(-13.5 \%)$ of Bolch et al. (2010). We estimate Cariboo Mountains glacier extent to have been $785 \pm 37 \mathrm{~km}^{2}$ in 1985 , versus $845 \mathrm{~km}^{2}$ reported by Bolch et al. (2010), a difference of $7.7 \%$. The Cariboo Mountains glacierized area for 1952 was $824 \pm 39 \mathrm{~km}^{2}$, still $2.5 \%$ less than the $845 \mathrm{~km}^{2}$ of the 1985 TRIM extents used in previous work (Schiefer et al., 2007; Bolch et al., 2010). Our results thus demonstrate that glacier loss during the period 1985-2005 was higher than during previous epochs, but that the absolute surface area lost in this period may have been overestimated in previous studies.

The relation between area change and glacier morphometry temporally varies (Table 5). For three periods - 19521985, 1985-2005, and 1952-2005 - absolute area change correlates $(p<0.05)$ negatively with glacier length and area, indicating that the larger glaciers in absolute terms lost more surface area in all periods. The relation between relative area change and both length and area varies with time. For the 


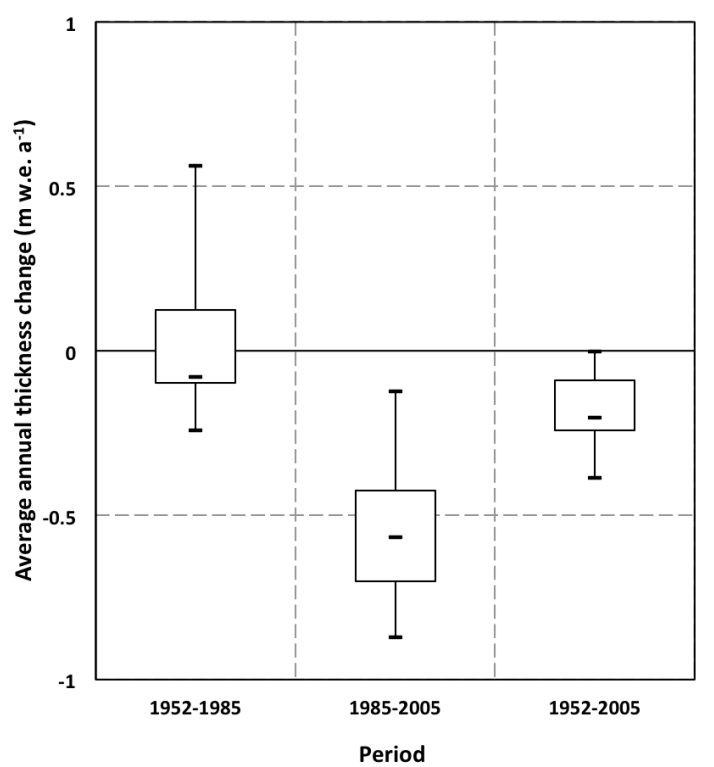

Figure 9. Box-and-whisker plots displaying maximum, interquartile range, median, and minimum of average annual thickness change in meters of water equivalent of seven glaciers for three periods.

period 1952-1985, we find $r$ values of -0.235 and -0.210 for length and area, respectively, and these correlations for length and area change to $0.328(p<0.10)$ and $0.316(p<$ 0.10 ) for the period 1985-2005. Large glaciers thus lost more relative area in the earlier period, whereas small glaciers lost more relative area in the latter period. Average glacier surface slope is correlated with absolute and relative area change in all periods, except for relative area change from 1985 to 2005, indicating steeper glaciers generally lost less absolute and relative surface area, except during the latter period when there was no correlation. Median glacier elevation is correlated with absolute area change for the period 1952-1985 $(r=0.358, p<0.05)$ and relative area change for the period 1952-2005 $(r=0.487, p<0.05)$, indicating that glaciers with more surface area at higher elevations experienced less area change in these two periods.

\subsection{Volume change}

Over the period 1952-2005, the seven glaciers of our study lost $-0.480 \pm 0.051 \mathrm{~km}^{3}$ w.e. Volume loss during the first period (1952-1985) totaled $-0.195 \pm 0.059 \mathrm{~km}^{3}$ w.e., and this loss accelerated to $-0.345 \pm 0.048 \mathrm{~km}^{3}$ w.e. during the later period (1985-2005). These volume losses correspond to respective mean thinning rates of $-0.14 \pm 0.04 \mathrm{~m}$ w.e. $\mathrm{a}^{-1}$ and $-0.50 \pm 0.07 \mathrm{~m}$ w.e. $\mathrm{a}^{-1}$ (Table 6 and Fig. 9). Net thinning rates over the period 1952 to 2005 averaged $-0.23 \pm 0.02 \mathrm{~m}$ w.e. $\mathrm{a}^{-1}$. Two glaciers, both of which advanced over the same period, markedly thickened between 1952 and 1985 (Table 6). Both of these glaciers thinned after
Table 6. Average annual thickness change in meters of water equivalent.

\begin{tabular}{lrrr}
\hline $\begin{array}{l}\text { Glacier } \\
\text { Id }\end{array}$ & $\begin{array}{r}\text { Thickness change } \\
1952-1985 \\
\left(\mathrm{~m} \text { w.e. } \mathrm{a}^{-1}\right)\end{array}$ & $\begin{array}{r}\text { Thickness change } \\
1985-2005 \\
\left(\mathrm{~m} \text { w.e. } \mathrm{a}^{-1}\right)\end{array}$ & $\begin{array}{r}\text { Thickness change } \\
1952-2005 \\
\left(\mathrm{~m} \text { w.e. } \mathrm{a}^{-1}\right)\end{array}$ \\
\hline 1 & $0.56 \pm 0.15$ & $-0.87 \pm 0.15$ & $-0.04 \pm 0.06$ \\
11 & $0.27 \pm 0.07$ & $-0.57 \pm 0.08$ & $-0.00 \pm 0.04$ \\
19 & $-0.09 \pm 0.16$ & $-0.82 \pm 0.22$ & $-0.39 \pm 0.14$ \\
24 & $-0.10 \pm 0.22$ & $-0.12 \pm 0.22$ & $-0.20 \pm 0.18$ \\
26 & $-0.02 \pm 0.25$ & $-0.41 \pm 0.30$ & $-0.14 \pm 0.21$ \\
28 & $-0.08 \pm 0.06$ & $-0.59 \pm 0.08$ & $-0.22 \pm 0.04$ \\
31 & $-0.24 \pm 0.20$ & $-0.44 \pm 0.23$ & $-0.27 \pm 0.17$ \\
Mean & $-0.14 \pm 0.04$ & $-0.50 \pm 0.07$ & $-0.23 \pm 0.02$ \\
\hline
\end{tabular}

1985, but experienced little net change from 1952 to 2005 . Five glaciers continuously thinned and receded.

Extrapolation of these thinning rates to unmeasured glaciers in the Cariboo Mountains yields volume losses of $-4.027 \pm 2.044$ and $-7.580 \pm 1.167 \mathrm{~km}^{3}$ w.e. for the periods $1952-1985$ and 1985-2005, respectively. We obtain lower estimates of volume change $(-2.312 \pm 2.170$ and $-6.242 \pm 1.315 \mathrm{~km}^{3}$ w.e) using elevation-averaged surfaceelevation change measurements from these seven glaciers.

\subsection{Relation to climate}

Surface temperature increased during the period of study, particularly after 1985 (Fig. 10). From the earlier (1952$1985)$ to the latter epoch (1986-2005), average temperatures increased by +0.38 and $+0.87^{\circ} \mathrm{C}$ for the ablation and accumulation season, respectively.

Accumulation season and annual precipitation decreased during the period of study, but little change occurred during the ablation season (Fig. 11). From the earlier (1952$1985)$ to the latter period (1986-2005), accumulation-season and annual precipitation decreased by $-32 \mathrm{~mm}(-3.2 \%)$ and $-44 \mathrm{~mm}(-3.0 \%)$, respectively, minor changes that are overwhelmed by large interannual variability.

Geopotential height $(700 \mathrm{hPa})$ anomalies, based on 1952 2005 mean fields, reveal an area of persistent low pressure in western Canada during the accumulation and ablation seasons for the periods 1952-1970 and 1971-1985 (Fig. 12). These low-pressure anomalies were centered over the Yukon Territory and northern BC from 1952 to 1970. These areas of low pressure weakened during the period 1971-1985 with a prominent trough along the Coast Mountains (ablation season) and a diffuse area of anomalously low pressure over much of central North America (accumulation season). A marked change in circulation occurred for the later period with anomalously high pressure present during the period 1986-2005, with ridges over south central Alaska (ablation season) and off the coast of northern $\mathrm{BC}$ and southeastern Alaska (accumulation season).

These synoptic conditions broadly accord with the Pacific Decadal Oscillation (PDO; Mantua et al., 1997), a pattern of 


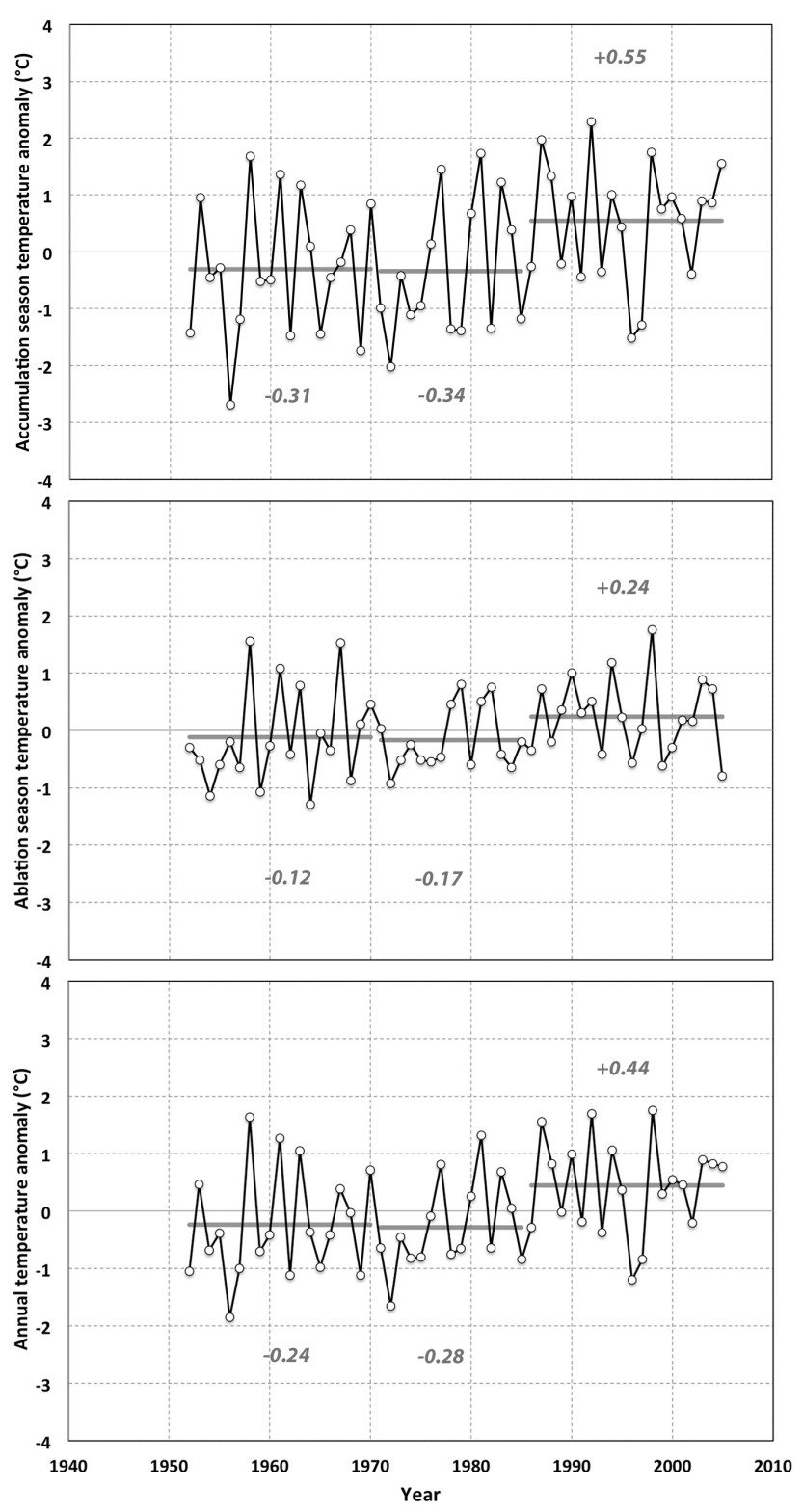

Figure 10. ClimateWNA temperature records of deviation from the long-term (1952-2005) mean of (a) average accumulation-season temperature, (b) average ablation season temperature, and (c) average annual temperature. Gray bars and values indicate averages for the periods 1952-1970, 1970-1985, and 1985-2005.

Pacific climate variability that persists for multiple decades and plays a prominent role in determining glacier mass balance in northwest North America (e.g., Bitz and Battisti, 1999). The earlier two periods (1950-1970 and 1971-1985) were largely or partially coincident with a cool phase of the PDO from 1947 to 1976. In contrast, the latest period (19852005) coincided with a warm phase of the PDO from 1977 to at least the mid-1990s.

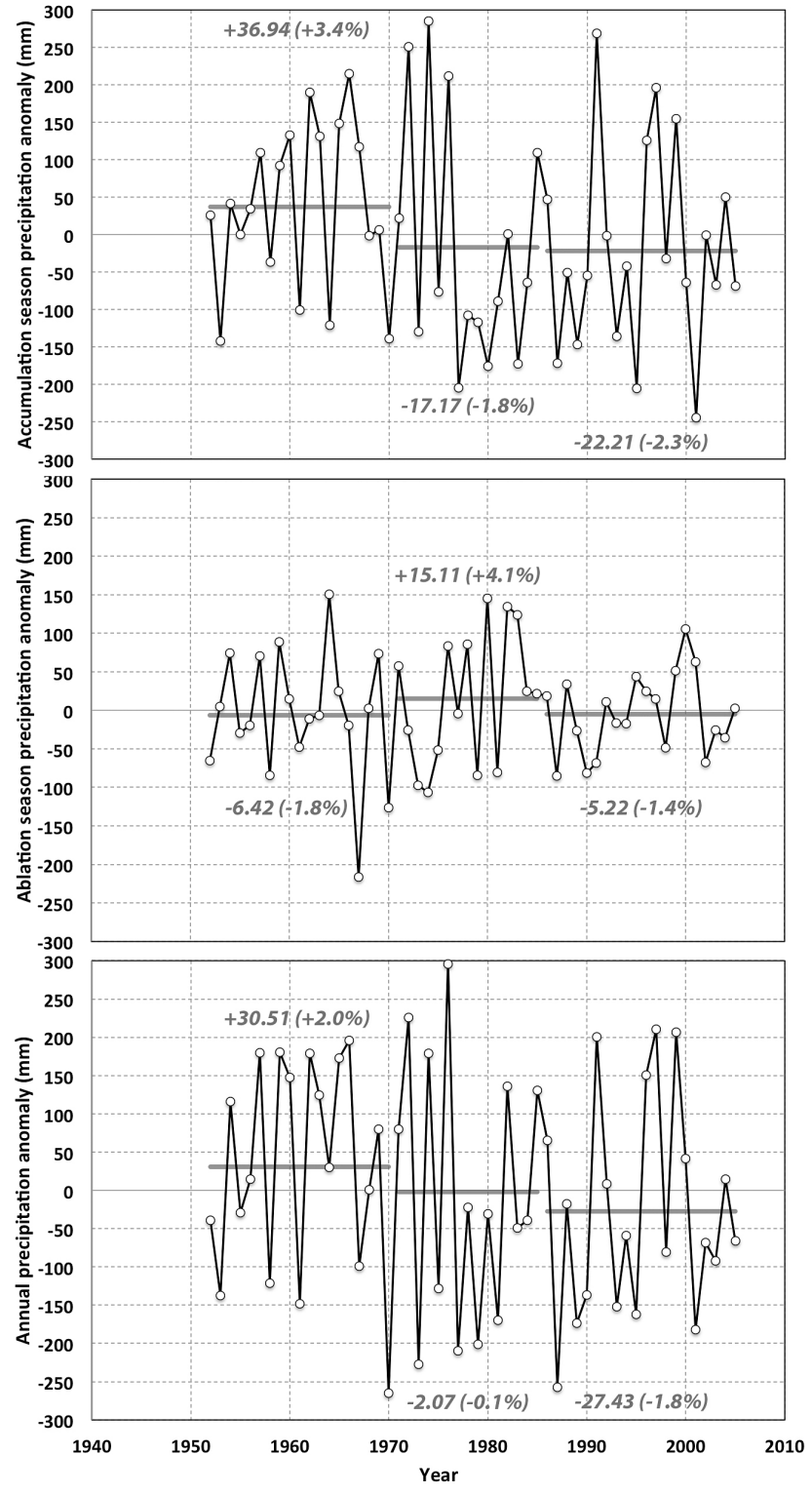

Figure 11. ClimateWNA precipitation records of deviation from the long-term (1952-2005) mean of (a) total accumulation-season precipitation, (b) total ablation season precipitation, and (c) total annual precipitation. Gray bars and values indicate averages for the periods 1952-1970, 1970-1985, and 1985-2005.

\section{Discussion}

\subsection{Regional representativeness}

Our glacier subset represents a compromise between regional representativeness and the availability of suitable aerial photography. We oversampled large glaciers as they will contribute most to volume change for a given region. While glaciers of the $1-5 \mathrm{~km}^{2}$ size class dominated volume change in the Cariboo Mountains for the period 1985-2005, losses from large glaciers $\left(>5 \mathrm{~km}^{2}\right)$ were even more important for 

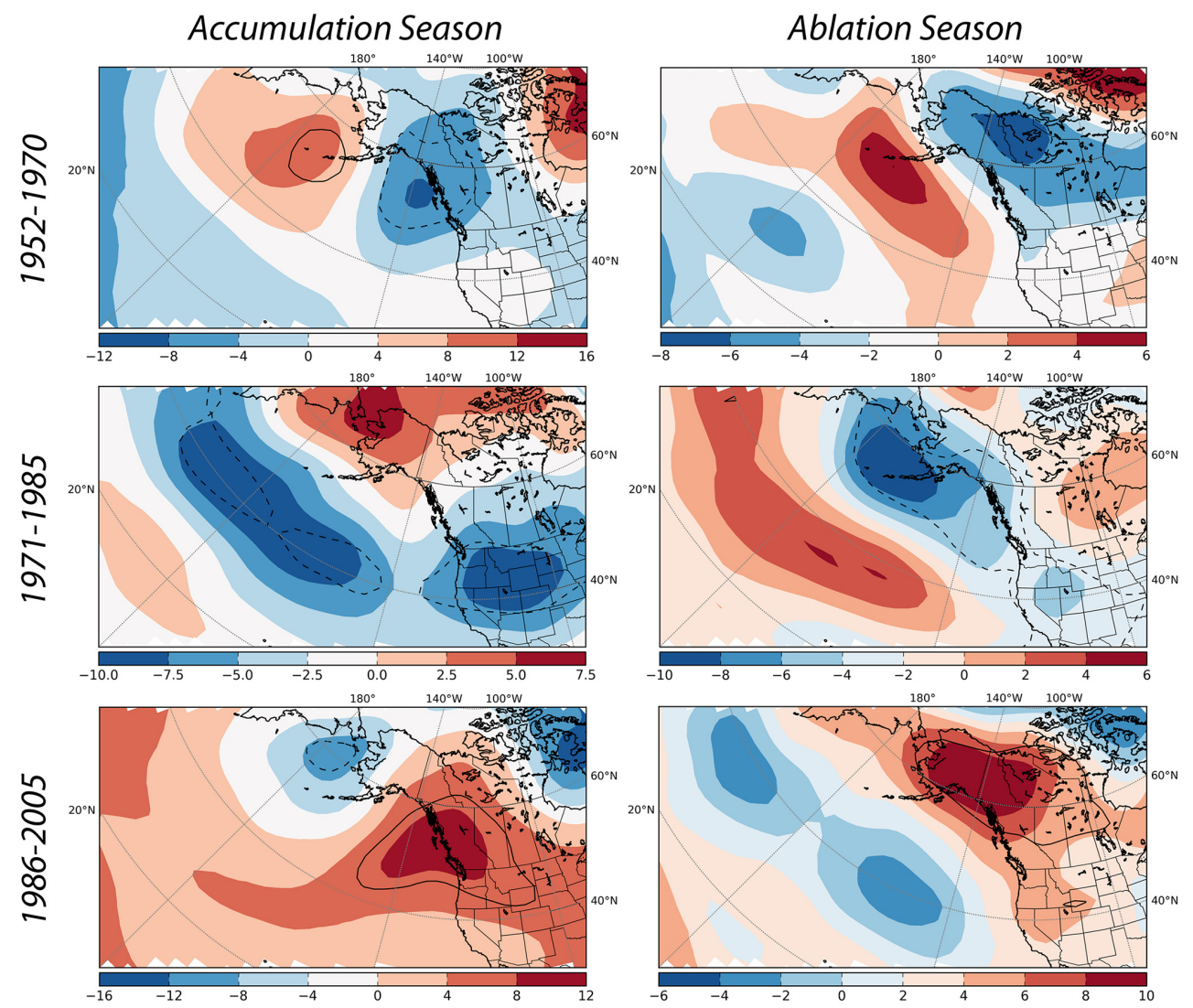

Figure 12. Geopotential height ( $700 \mathrm{hPa}$ ) anomalies $(\mathrm{m})$ for the accumulation and ablation seasons. Color scale shows magnitude of anomaly. Data for the period 1952-2005 define the mean fields. Dashed and solid contours respectively denote negative and positive anomalies that are significantly different $(p<0.05)$ from the mean at a given grid point. Reanalysis data were downloaded from the National Oceanographic and Atmospheric Administration's Earth System Research Laboratory (http://www.esrl.noaa.gov/psd/data/gridded/tables/monthly.html).

previous epochs. The two largest glaciers for which we calculated volume change, for example, accounted for $94 \%$ of the total volume change for seven glaciers from 1952 to 1985 , and $75 \%$ from 1985 to 2005 . Selection of a representative subset of glaciers for a region is difficult, especially when glacier change is assessed over multiple epochs.

Most studies of glacier change note increased scatter of percent area change for smaller glaciers (Serandbrei-Barbero et al., 1999; Kääb et al., 2001; Paul, 2002; Paul et al., 2004; DeBeer and Sharp, 2007; Andreassen et al., 2008; Bolch et al., 2010; Paul and Andreassen, 2009). This scatter may arise from the influence of local topographic factors (DeBeer and Sharp, 2007; Paul and Andreassen, 2009). Kääb et al. (2001) concluded that this scatter could also be the result of using low-resolution satellite imagery, or from the fast response times of small glaciers. Late-lying seasonal snow may also impact the inferred relative area change in small glaciers, and could play a role in the observation of increased scatter for smaller glaciers. To assess this factor we compared the standard deviation in relative area change in the smallest glaciers as measured for 28 glaciers in both Bolch et al. (2010) and in our study, which, based on our analysis, is less affected by late-lying seasonal snow cover. The standard deviation of relative area change from 1985 to 2005 for the Bolch et al. (2010) inventory is $8.1 \%$ for the smallest glaciers $\left(<1.0 \mathrm{~km}^{2}\right)$, whereas in our study it is $5.8 \%$. This difference is significant ( $F$ test, $p<0.05$ ); it supports our hypothesis that late-lying seasonal snow plays a role in observations of increased scatter for smaller glaciers, and that the TRIM mapping of 1985 glacier extents errantly mapped seasonal snow cover as glacierized area.

\subsection{Area change}

Our results indicate net recession of Cariboo Mountains glaciers from 1952 to 2005 , consistent with other studies of glacier change in BC (DeBeer and Sharp, 2007; Brewis, 2012; Tennant et al., 2012; Tennant and Menounos, 2013). While net glacier change in our 33-glacier subset over this period is negative $\left(-15.11 \pm 1.89 \mathrm{~km}^{2}\right.$ or $\left.-10.6 \pm 2.9 \%\right)$, recession for 11 of these glaciers did not exceed measurement error. Nine of these 11 glaciers advanced during the period 1952-1985. 
Our finding of glacier advance in the period 1952-1985 accords with the advance in the Premier Range described by Luckman et al. (1987) and with glacier expansion elsewhere in BC during this period (Koch et al., 2009; Menounos et al., 2009; Brewis, 2012; Tennant and Menounos, 2013). Studies that only determine net recession over a multi-decadal period (e.g., DeBeer and Sharp, 2007, 2009; Jiskoot et al., 2009) may not capture minor advances like those of the present study.

During the period 1985-2005, glaciers shrank (mean relative area change per annum) 8 times faster than the period 1952-1985, and 5 times faster than 1970-1985 (Fig. 7). Annual recession of Castle Creek Glacier (glacier 28) increased from about $-10 \mathrm{~m} \mathrm{a}^{-1}$ in the early to mid-1980s to about $-40 \mathrm{~m} \mathrm{a}^{-1}$ in the early 1990s (Beedle et al., 2009). Tennant and Menounos (2013) also found increased recession rates for glaciers of the Columbia Icefield of $\mathrm{BC}$ and Alberta, which increased after 1979 and again after 2000.

\subsection{Thickness change}

Observed thinning rates during the period 1952-2005 averaged $-0.23 \pm 0.12 \mathrm{mw}$ w.e. $\mathrm{a}^{-1}$, resulting in a net loss of $-0.48 \pm 0.05 \mathrm{~km}^{3}$ w.e. (Table 6). This rate of thinning is considerably less then long-term thinning rates for glaciers of the Columbia Icefield $\left(-0.6 \pm 0.3 \mathrm{~m}_{\text {w.e. }} \mathrm{a}^{-1}\right.$; Tennant and Menounos, 2013) and Alaskan glaciers $\left(-0.48 \pm 0.10\right.$ m w.e. $\mathrm{a}^{-1}$; Berthier et al., 2010). However, our average thinning rate is similar to those reported for nine North America glaciers for the period from the mid-1950s to the mid-1990s, which range from +0.01 to -0.61 and average $-0.21 \mathrm{~m}$ w.e. $\mathrm{a}^{-1}$ (Sapiano et al., 1998).

From 1952 to 1985 , thinning rates averaged $-0.14 \pm 0.16 \mathrm{~m}^{2}$.e. $\mathrm{a}^{-1}$ and glaciers lost $-0.20 \pm 0.06 \mathrm{~km}^{3}$ w.e. The two smallest glaciers of our study thickened and advanced over the same period. Brewis (2012) also found that four of six glaciers in the Canoe River basin (Fig. 1) thickened and advanced during the period 1955-1970.

The post-1985 accelerated thinning of Cariboo Mountains glaciers agrees with other studies of glacier change in northwest North America (e.g., Rasmussen and Conway, 2004; Brewis, 2012; Tennant and Menounos, 2013). Schiefer et al. (2007) found that over the period 19851999, and using different density assumptions, glaciers of the Cariboo Mountains thinned at a rate of $-0.58 \mathrm{~m}$ w.e. $\mathrm{a}^{-1}$ and lost $-7.06 \mathrm{~km}^{3}$ w.e. Using our two different methods of extrapolation described in Sect. 3.3, our estimates yield comparable estimates of ice loss $\left(-6.24 \pm 1.32 \mathrm{~km}^{3}\right.$ and $-7.58 \pm 1.17 \mathrm{~km}^{3}$ ) for the Cariboo Mountains.

Unlike the period 1985-2005, our methods of extrapolation to Cariboo Mountains glaciers yield significantly different volume change estimates for the period 1952-1985 $\left(-4.03 \pm 2.04 \mathrm{~km}^{3}\right.$ versus $\left.-2.31 \pm 2.17 \mathrm{~km}^{3}\right)$. This discrepancy could arise from the time-varying magnitude of ice dy- namics leading to extrapolation from a small subset performing poorly during epochs with higher surface mass balance and where some glaciers advanced. We recommend further study of extrapolation of regional volume change from a subset of glaciers, but with a more robust sample size to better constrain regional variability of surface-elevation change.

\subsection{Relations of extent change to glacier morphometry}

Glacier surface area is the single morphometric parameter that commonly correlates with extent change (SerandbreiBarbero et al., 1999; Hoelzle et al., 2003; Paul et al., 2004; Andreassen et al., 2008; Bolch et al., 2010; Paul and Andreassen, 2009). From 1985 to 2005, we find average relative area change of $-11.2,-9.3,-7.5,-5.4$, and $-5.4 \%$ for our five size classes, arranged from smallest to largest (Table 3). Surface area and relative area change during the period 1985-2005 are weakly correlated $(p<0.1)$, indicating generally more relative area change for smaller glaciers (Table 5). However, from 1952 to 1985, a period with reduced rates of recession or advance, this does not apply; average relative area change was $-2.5,+3.4,-4.6,-9.0$, and $-4.1 \%$ for the same size classes, and the $r$ value (not significant) is negative. It appears that the magnitude of glacier change is not simply related to dimensional attributes of a given glacier; they apparently vary with differing climatic regimes.

Studies have typically found no significant correlation among other morphometric parameters and area change (Paul, 2002; Granshaw and Fountain, 2006; Andreassen et al., 2008; Bolch et al., 2010; Paul and Andreassen, 2009). Other parameters include slope, aspect, and median, minimum, and maximum elevation. We, however, find correlation between slope and absolute area in all periods. Slope correlates with relative area change from 1952 to 1985, and on a net basis from 1952 to 2005 , but not for the latter period 1985-2005 (Table 5). This relation, indicating that the steeper glaciers lost less absolute and relative surface area, may be spurious, however, as slope is highly correlated with glacier surface area and length (e.g., Hoelzle et al., 2003).

We also find that median, minimum, and maximum glacier elevations (along with elevation range) correlate with area change, but the strength of these associations is not constant through time (Table 5). A study with a larger sample size is required to assess whether the temporal changes we observed in this study are present for other mountain ranges, and how time-variable glacier dynamics might obscure relations between extent change and glacier geometry.

\subsection{Relations to climate}

Mean annual and seasonal temperatures increased from 1952 to 2005 , particularly after 1985 , whereas wintertime precipitation slightly decreased (Figs. 10 and 11). Observed mass and area loss coincided with intervals of increased (de- 
creased) temperatures (precipitation), a finding in agreement with previous studies for glaciers in the Cariboo Mountains (Luckman et al., 1987; Brewis, 2012). Previous studies implicate increases in surface air temperatures as the recent cause for accelerated mass loss of North American glaciers in maritime environments (Rasmussen and Conway, 2004; Arendt et al., 2009). Tennant and Menounos (2013) also suggest that decreases in precipitation contribute to mass loss of the Columbia Icefield of the Canadian Rocky Mountains.

There was negligible change in surface temperatures from 1952-1970 to 1971-1986, but following 1985, climate warmed in the Cariboo Mountains (Fig. 10). After 1985, temperatures increased during the ablation season and doubled during the accumulation season.

Precipitation consistently decreased over the three periods of analysis for the accumulation season and annually (Fig. 11). Decreased annual precipitation is primarily an accumulation-season phenomenon, whereas average ablation season precipitation negligibly changed. Cool accumulationseason temperatures from 1971 to 1985 may have counteracted decreased precipitation, leading to snow accumulation comparable to that of the period 1952-1970. Some, but not all, glaciers thickened and advanced between 1952 and 1985 , a result of both individual glacier hypsometry leading to more retained accumulation, and length and slope angle that led to a more rapid terminus response.

ClimateWNA records indicate that wet, cool periods coincide with anomalous low-pressure, whereas dry and warm intervals were associated with high-pressure anomalies (Fig. 12). Others note high-pressure anomalies over northwest North America after the late 1970s with coincident glacier recession and thinning (e.g., Bitz and Battisti, 1999; Hodge et al., 1998; Rasmussen and Conway, 2004). Glacier change in the Cariboo Mountains and its relation to broad scale changes in atmospheric circulation broadly accord with these previous studies, and, importantly, our work expands the spatial domain of these climate anomalies and how they influenced glacier change during the mid-20th to early $21 \mathrm{st}$ centuries.

Previous studies suggest that glaciologists need to further examine intra- and inter-regional mass-balance variability (Braithwaite, 2002), and conclude that there are no means of making an a priori selection of a regionally representative benchmark glacier (Fountain et al., 2009). The paucity of traditional mass-balance and glacier length change measurements limits assessments of regional representativeness. Widespread use of remotely sensed imagery to derive glacier extents and surface elevation, however, provides one method to document changes of glacier extent and volume change on decadal timescales. We demonstrate that comprehensive glacier inventories and assessments of decadal area and thickness change can be used to make an informed a priori selection of a representative subset of glaciers. Regional representativeness will be variable with respect to glacier morphometry, climate and glacier response, however. Selec- tion of benchmark glaciers and representative glacier subsets, as well as testing of the regional representativeness of existing benchmark glaciers (e.g., Fountain et al., 2009), should be based on regional glacier morphometry, recent decadal glacier extent and thickness change, and with respect to varying glacier response in different climatic regimes.

\section{Conclusions}

During the period 1952-2005, glaciers of the Cariboo Mountains receded at a rate of $0.19 \pm 0.05 \% \mathrm{a}^{-1}$. Slow glacier recession rates characterized the epoch 1952-1985 $\left(-0.05 \pm 0.10 \% \mathrm{a}^{-1}\right)$, and some glaciers advanced. After 1985, glacier recession rates increased 8-fold $\left(-0.41 \pm 0.12 \% \mathrm{a}^{-1}\right)$. Thinning rates also accelerated from $-0.143 \pm 0.043 \mathrm{mw}^{-e . \mathrm{a}^{-1}}(1952-1985)$ to $-0.500 \pm 0.070 \mathrm{~m}$ w.e. $\mathrm{a}^{-1}$ from 1985 to 2005 . Temperatures increased from 1952 to 2005 , primarily after 1985 , whereas accumulation-season precipitation decreased over the period of study, indicating that both increases in temperature and decreases in precipitation played important roles in forcing the observed pattern of glacier change.

The inventory of Bolch et al. (2010) marginally overestimated the recession of Cariboo Mountains glaciers from 1985 to 2005 . For 28 common glaciers, our extents average $2 \%$ smaller than the 2005 extents generated with the semiautomated method of Bolch et al. (2010) and 5\% smaller than the 1985 extents of the TRIM data set, likely due to mapping of late-lying seasonal snow as glacierized area in the TRIM data set. When uncertainties are taken into account, however, the average difference between our subset and that of Bolch et al. (2010) is not significant.

Our results indicate that relations between glacier change and dimensional attributes of the glaciers of this study are not stable through time; this non-stationarity may be related to ice dynamics and the complex way glaciers respond to changes in surface mass balance.

Acknowledgements. We acknowledge research funding provided through the Western Canadian Cryospheric Network (from the Canadian Foundation for Climate and Atmospheric Sciences), the Natural Sciences and Engineering Research Council of Canada (NSERC), the Pacific Institute for Climate Solutions (Graduate Fellowship to M. Beedle), and the University of Northern British Columbia (graduate scholarship to M. Beedle). We also thank the province of British Columbia and Natural Resources Canada for access to aerial photography, Caillin Smith and Tyler Sylvestre for photogrammetric scanning, and Cardinal Systems for providing Vr Mapping software licenses and support. Stephen Déry, Peter Jackson, and Andrew Fountain provided comments that significantly improved our analysis and manuscript. We are appreciative of detailed reviews by Heidi Escher-Vetter and Chris DeBeer, and the efforts of editor Andreas Kääb.

Edited by: A. Kääb 


\section{References}

Abermann, J., Lambrecht, A., Fischer, A., and Kuhn, M.: Quantifying changes and trends in glacier area and volume in the Austrian Ötztal Alps (1969-1997-2006), The Cryosphere, 3, 205215, doi:10.5194/tc-3-205-2009, 2009.

Andreassen, L. M., Paul, F., Kääb, A., and Hausberg, J. E.: Landsatderived glacier inventory for Jotunheimen, Norway, and deduced glacier changes since the 1930s, The Cryosphere, 2, 131-145, doi:10.5194/tc-2-131-2008, 2008.

Arendt, A. A., Echelmeyer, K. A., Harrison, W. D., Lingle, C. S., and Valentine, V. B.: Rapid wastage of Alaska glaciers and their contribution to rising sea level, Science, 297, 382-385, 2002.

Arendt, A., Echelmeyer, K., Harrison, W., Lingle, C., Zirnheld, S., Valentine, V., Ritchie, B., and Druckenmiller, M.: Updated estimates of glacier volume changes in the western Chugach Mountains, Alaska, and a comparison of regional extrapolation methods, J. Geophys. Res., 111, F03019, doi:10.1029/2005JF000436, 2006.

Arendt, A., Walsh, J., and Harrison, W.: Changes of glaciers and climate in northwestern North America during the late 20th century, J. Climate, 22, 4117-4134, 2009.

Bahr, D. B. and Radic, V.: Significant contribution to total mass from very small glaciers, The Cryosphere, 6, 763-770, doi:10.5194/tc-6-763-2012, 2012.

Barrand, N. E., Murray, T., James, T. D., Barr, S. L., and Mills, J. P.: Optimizing photogrammetric DEMs for glacier volume change assessment using laser-scanning derived ground-control points, J. Glaciol., 55, 106-116, 2009.

Barrand, N. E., James, T. D., and Murray, T.: Spatio-temporal variability in elevation changes of two high-Arctic valley glaciers, J. Glaciol., 56, 771-780, 2010.

Beedle, M. J., Menounos, B., Luckman, B. H., and Wheate, R.: Annual push moraines as climate proxy, Geophys. Res. Lett., 36, L20501, doi:10.1029/2009GL039533, 2009.

Beedle, M. J., Menounos, B., and Wheate, R.: An evaluation of mass balance techniques applied to Castle Creek Glacier, British Columbia, Canada, J. Glaciol., 60, 262-276, 2014.

Berthier, E., Schiefer, E., Clarke, G. K. C., Menounos, B., and Rémy, F.: Contribution of Alaskan glaciers to sea-level rise derived from satellite imagery, Nat. Geosci., 3, 92-95, doi:10.1038/NGEO737, 2010.

Bitz, C. M. and Battisti, D. S.: Interannual to decadal variability in climate and the glacier mass balance in Washington, western Canada, and Alaska, J. Climate, 12, 3181-3196, 1999.

Bogdal, C., Schmid, P., Zennegg, M., Anselmetti, F. S., Scheringer, M., and Hunberbühler, K.: Blast from the past: melting glaciers as a relevant source for persistent organic pollutants, Environ. Sci. Technol., 43, 8173-8177, 2009

Bolch, T., Menounos, B., and Wheate, R.: Landsat-based inventory of glaciers in western Canada, 1985-2005, Remote Sens. Environ., 114, 127-137, 2010.

Braithwaite, R. J.: Glacier mass balance: the first 50 years of international monitoring, Prog. Phys. Geog., 26, 76-95, 2002.

Brewis, T. B.: Glacier change and contribution to streamflow in the Canoe Basin, British Columbia, 1948-2005 (Master's Thesis), University of Northern British Columbia, 2012.

British Columbia (BC) Ministry of Environment: Specifications for aerial triangulation. Surveys and Resource Mapping, Province of British Columbia, Victoria, BC, 1998.
Daly, C., Gibson, W. P., Taylor, G. H., Johnson, G. L., and Pasteris, P.: A knowledge-based approach to the statistical mapping of climate, Clim. Res., 22, 99-113, 2002.

DeBeer, C. M. and Sharp, M. J.: Recent changes in glacier area and volume within the southern Canadian Cordillera, Ann. Glaciol., 46, 215-221, 2007.

DeBeer, C. M. and Sharp, M. J.: Topographic influences on recent changes of very small glaciers in the Monashee Mountains, British Columbia, Canada, J. Glaciol., 55, 1-10, 2009.

Déry, S. J., Clifton, A., MacLeod, S., and Beedle, M. J.: Blowing snow fluxes in the Cariboo Mountains of British Columbia, Canada. Arct. Antarct. Alp. Res., 42, 188-197, doi:10.1657/1938-4246-42.2.188, 2010.

Environment Canada: 1981-2010 Climate Normals \& Averages. Meteorological Service of Canada, Environment Canada, available at: http://climate.weather.gc.ca/climate_normals/), 2012.

Fountain, A. G., Hoffman, M. J., Granshaw, F., and Riedel, J.: The "benchmark glacier" concept - does it work? Lessons from the North Cascade Range, USA, Ann. Glaciol., 50, 163-168, 2009.

Gardner, A. S., Moholdt, G., Wouters, B., Wolken, G. J., Burgess, D. O., Sharp, M. J., Cogley, J. G., Braun, C., and Labine, C.: Sharply increased mass loss from glaciers and ice caps in the Canadian Arctic Archipelago, Nature, 473, 357-360, doi:10.1038/nature10089, 2011.

Granshaw, F. D. and Fountain, A. G.: Glacier change (1958-1998) in the North Cascades National Park Complex, Washington, USA, J. Glaciol., 52, 251-256, 2006.

Hodge, S. M., Trabant, D. C., Krimmel, R. M., Heinrichs, T. A., March, R. S., and Josberger, E. G.: Climate variations and changes in mass of three glaciers in western North America, J. Climate, 11, 2161-2179, 1998.

Hoelzle, M., Haeberli, W., Dischl, M., and Peschke, W.: Secular glacier mass balances derived from cumulative glacier length changes, Global Planet. Change, 36, 295-306, 2003.

Hood, E., Fellman, J., Spencer, R. G. M., Hernes, P. J., Edwards, R., D'Amore, D., and Scott, D.: Glaciers as a source of ancient and labile organic matter to the marine environment, Nature, 462, 1044-1047, doi:10.1038/nature08580, 2009.

Huss, M.: Density assumptions for converting geodetic glacier volume change to mass change, The Cryosphere, 7, 877-887, doi:10.5194/tc-7-877-2013, 2013.

Jiskoot, H., Curran, C. J., Tessler, D. L., and Shenton, L. R.: Changes in Clemenceau Icefield and Chaba Group glaciers, Canada, related to hypsometry, tributary detachment, lengthslope and area-aspect relations, Ann. Glaciol., 50, 133-143, 2009.

Kääb, A., Paul, F., Maisch, M., Hoelzle, M., and Haeberli, W.: The new remote sensing derived Swiss glacier inventory: II. First results, Ann. Glaciol., 34, 362-366, 2001.

Kääb, A. and Vollmer, M.: Surface geometry, thickness changes and flow fields on creeping mountain permafrost: automatic extraction by digital image analysis, Permafrost Periglac., 11, 315-326, 2000.

Kalnay, E. M., Kanamitsu, R., Kistler, W., Collins, W., Deaven, D., Gandin, L., Iredell, M., Saha, S., White, G., Woollen, J., Zhu, Y., Chelliah, M., Ebisuzaki, W., Higgins, W., Janowiak, J., Mo, K. C., Ropelewski, C., Wang, J., Leetmaa, A., Jenne, R., and Joseph, D.: The NCEP/NCAR 40-year reanalysis project, B. Am. Meteorol. Soc., 77, 3, 437-471, 1996. 
Koblet, T., Gärtner-Roer, I., Zemp, M., Jansson, P., Thee, P., Haeberli, W., and Holmlund, P.: Reanalysis of multi-temporal aerial images of Storglaciären, Sweden (1959-99) - Part 1: Determination of length, area and volume changes, The Cryosphere, 4, 333-343, doi:10.5194/tc-4-333-2010, 2010.

Koch, J., Menounos, B., and Clague, J. J.: Glacier change in Garibaldi Provincial Park, southern Coast Mountains, British Columbia, since the Little Ice Age, Global Planet. Change, 66, 161-178, 2009.

Luckman, B. H., Harding, K. A., and Hamilton, J. P.: Recent glacier advances in the Premier Range, British Columbia, Can. J. Earth Sci., 24, 1149-1161, 1987.

Mantua, N. J., Hare, S. R., Zhang, Y., Wallace, J. M., and Francis, R. C.: A Pacific interdecadal climate oscillation with impacts on salmon production. B. Am. Meteorol. Soc., 78, 1069-1079, 1997.

Marshall, S. J., White, E. C., Demuth, M. N., Bolch, T., Wheate, R., Menounos, B., Beedle, M. J., and Shea, J. M.: Glacier water resources on the eastern slopes of the Canadian Rocky Mountains, Can. Water Resour. J., 36, 109-134, 2011.

Maurer, M. K., Menounos, B., Luckman, B. H., Osborn, G., Clague, J. J., Beedle, M. J., Smith, R., and Atkinson, N.: Late Holocene glacier expansion in the Cariboo and northern Rocky Mountains, British Columbia, Canada, Quaternary Sci. Rev., 51, 7180, 2012.

Menounos, B., Osborn, G., Clague, J. J., and Luckman, B.: Latest Pleistocene and Holocene glacier fluctuations in western Canada, Quaternary Sci. Rev., 28, 2049-2074, 2009.

Mitchell, T. D. and Jones, P. D.: An improved method of constructing a database of monthly climate observations and associated high-resolution grids, Int. J. Climatol., 25, 693-712, 2005.

Moore, R. D., Fleming, S. W., Menounos, B., Wheate, R., Fountain, A., Stahl, K., Holm, K., and Jakob, M.: Glacier change in western North America: influences on hydrology, geomorphic hazards and water quality, Hydrol. Process., 24, 42-61, 2009.

Paul, F.: Changes in glacier area in Tyrol, Austria, between 1969 and 1992 derived from Landsat 5 Thematic Mapper and Austrian Glacier Inventory data, Int. J. Remote Sens., 23, 787-799, 2002.

Paul, F. and Andreassen, L. M.: A new glacier inventory for the Svartisen region, Norway, from Landsat ETM+ data: challenges and change assessment, J. Glaciol., 55, 607-618, 2009.
Paul, F. and Haeberli, W.: Spatial variability of glacier elevation changes in the Swiss Alps obtained from two digital elevation models, Geophys. Res. Lett., 35, L21502, doi:10.1029/2008GL034718, 2008.

Paul, F., Kääb, A., Maisch, M., Kellenberger, T., and Haeberli, W.: Rapid disintegration of Alpine glaciers observed with satellite data, Geophys. Res. Lett., 31, L21402, doi:10.1029/2004GL020816, 2004.

Radić, V. and Hock, R.: Regionally differentiated contribution of mountain glaciers and ice caps to future sea-level rise, Nat. Geosci., 4, 91-94, doi:10.1038/NGEO1052, 2011.

Rasmussen, L. A. and Conway, H.: Climate and glacier variability in western North America, J. Climate, 17, 1804-1815, 2004.

Rolstad, C., Haug, T., and Denby, B.: Spatially integrated geodetic glacier mass balance and its uncertainty based on geostatistical analysis: application to the western Svartisen ice cap, J. Glaciol., 55, 666-680, 2009.

Sapiano, J. J., Harrison, W. D., and Echelmeyer, K. A.: Elevation, volume and terminus changes in nine glaciers in North America, J. Glaciol., 44, 119-135, 1998.

Schiefer, E. and Gilbert, R.: Reconstructing morphometric change in a proglacial landscape using historical aerial photography and automated DEM generation, Geomorphology, 88, 167-178, 2007.

Schiefer, E., Menounos, B., and Wheate, R.: Recent volume loss of British Columbia glaciers, Canada, Geophys. Res. Lett., 34, L16503, doi:10.1029/2007GL030780, 2007.

Serandbrei-Barbero, R., Rabagliati, R., Binaghi, E., and Rampini, A.: Glacial retreat in the 1980s in the Breonie, Aurine and Pusteresi groups (eastern Alps, Italy) in Landsat TM images, Hydrol. Sci., 44, 279-296, 1999.

Tennant, C., Menounos, B., Wheate, R., and Clague, J. J.: Area change of glaciers in the Canadian Rocky mountains, 1919 to 2006, The Cryosphere, 6, 1541-1552, doi:10.5194/tc-6-15412012, 2012.

Tennant, C. and Menounos, B.: Glacier change of the Columbia Icefield, Canadian Rocky Mountains, 1919-2009, J. Glaciol. 59, 671-686, doi:10.3189/2013JoG12J135, 2013.

Wang, T., Hamann, A., Spittlehouse, D., and Murdock, T. N.: ClimateWNA - High-resolution spatial climate data for western North America, J. Appl. Meteorol. Clim., 61, 16-29, 2012. 